\title{
Culture in The Balance: Why CANADA's COPYRIGHT AMENDMENTS WILL BACKFIRE ON Canadian Culture by Paralyzing the Private RADIO INDUSTRY
}

\author{
o Canada, we stand on guard for Thee! ${ }^{1}$
}

\section{INTRODUCTION}

In many ways, Canada and the United States enjoy a mutually beneficial and unprecedented relationship. ${ }^{2}$ That the two countries share the world's longest unprotected border, in itself, underscores the unique opportunity for Canada and the United States to reciprocally benefit each other. The countries have been "comrades in arms and in the grand endeavors to rebuild a world shattered by war," as well as allies in NORAD and NATO. ${ }^{3}$ Economically, "Canada does twice as much business with the United States as [the Untied States'] next biggest trading partner, Japan." Philosophically, the two countries "see the world in almost the same way" and "are cut from the same cloth, both offspring of a vanished British empire; both pluralist democracies tempered by constitutions; both speaking

1. The reiterated last line of Canada's national anthem, approved by the Parliament of Canada in 1967, is a resolute expression of the country's determination to retain its identity. Frank E. Manning, Reversible Resistance: Canadian Popular Culture and the American Other, in THE BEAVER BITES BACK? 3 (David H. Flaherty \& Frank M. Manning eds., 1993) [hereinafter BEAVER]. Northrop Frye, the internationally famous literary and cultural critic, has commented extensively on Canada's "garrisọn mentality" - an attitude "defensive and separatist." Images of Canada: Journey Without Arrival (Canadian Broadcast Corporation [CBC] 1975). The novelist Margaret Atwood described the same persistent phenomenon in Survival: A THEMATIC GuIDE To CANADIAN LITERATURE (1972); see also BARBARA GODARD, THE CANADIAN ENCYClOPEDIA 143 (James H. Marsh ed., 2d ed. 1988).

2. See JoHn SLOAN DICKEY, CANADA AND THE AMERICAN PRESENCE at vii (1975). "We are dealing with an ongoing interplay of vastness and intimacy . . . all gathered together in a drama of disparities and of alternating attraction and rejection that has no counterpart in the international community." Id.

3. Bernard Ostry, American Culture in a Changing World, in BEAVER, supra note 1, at 37 .

4. Id. See Business Costs Lowest in Canada, Canada Q., Oct. 1997:

U.S. merchandise exports to Canada in the first half of 1997 totaled [U.S.] $\$ 75.8$ billion, an increase of 10 [\%] over the same period [in 1996]. The increase, about [U.S.] $\$ 8$ billion, was more than the U.S.'s total exports in the six months to markets such as France, Hong Kong or China.

Id. See generally Stephen R. Konigsberg, Think Globally, Act Locally: North American Free Trade, Canadian Cultural Industry Exemption, and the Liberalization of the Broadcast Ownership Laws, 12 CARDOzo ARTS \& ENT. L.J. 281 (1993). In 1989, “\$200 billion worth of goods flowed between the two nations." Id. at 283 . "In that same year shipments from the U.S. to Canada accounted for more than $20 \%$ of the value of all U.S. exports of merchandise ...." Id. Reciprocally, "in 1991, Canadian exports [made up] 19\% of all U.S. imports, an amount matched only by Japan." Id. 
the language of liberty and dollars. ${ }^{n 5}$

Considerable ambiguity undermines this relationship, however, as the U.S. entertainment industries threaten to consume Canadian culture. ${ }^{6}$ More than any other country with similar concerns, Canada is especially susceptible to this phenomenon because of its immediate proximity to the United States. ${ }^{7}$ That more than eighty percent of the Canadian population lives within 100 kilometers of the U.S. border exacerbates this vulnerability, as does the vast difference in population size. ${ }^{8}$ This makes maintaining a national identity distinct from that of the United States increasingly difficult for Canada. Simply put, the stereotype is that there is no true Canadian culture. It has even been suggested, by extension of this misconception, that Canada should simply join the United States for the sake of convenience. ${ }^{9}$

5. Ostry, supra note 3, at 37. See DickEY, supra note 2, at 6. Dickey admonishes that "Americans would do well not to mistake the appearance of similarity or similar terminology for the reality of similarity." Id. Even the appearance of similarity breaks down quickly when one pays attention. For example, there is regionalism in the United States in that the country is "divided and dispersed by fifty different state governments, while in Canada the geographic definition and size of only ten provinces give regionalism a cultural integrity and a political authority of its own." Id.

6. The U.S. entertainment industries unapologetically impose American culture on the rest of the world. The potent mediums of music, radio, books, film, and television represent the greatest export of the United States as a result of aggressive pursuit of foreign markets. See Andrew Carlson, The Country Music Television Dispute: An Illustration of the Tensions Between Canadian Cultural Protectionism and American Entertainment Exports, 6 MINN. J. GLOBAL TRADE 585 (Summer 1997).

7. Id. at 586-87. The number of nations asserting rights to protect their cultural industries against the U.S. onslaught is rising rapidly. See also Rudy Fenwick, Canadian Society, in THE ACsUS PAPERS (1989). Discussing the notion of "nation building," the author argues that although these issues are more sharply drawn in Canada, they are not uniquely Canadian concerns. Id. at 48.

[R]ecent American political campaigns and product advertising-on the one hand promoting a free, open world market, but on the other encouraging consumers to "buy American" [while] worrying about the effects of the trade deficit and foreign investments on the nation's economy-[suggest] that these are shared concerns in a changing world.

Id.

8. Carlson, supra note 6, at 586-87. See also Fenwick, supra note 7, at 4. "Most basic of all is the disparity in size of the two populations, the United States being about ten times larger than Canada's twenty-two million." DiCKEY, supra note 2, at 4. The author argues that this disparity in population size leads to almost every other disparity, and few flow against the enormous difference in population size. The few exceptions to this rule that do exist- "for example, the fact that Canadians on a per capita basis in 1971 had $\$ 4,476.19$ of life insurance compared to $\$ 775.60$ in the United States"-indicate "inconspicuous but culturally significant differences in the two societies." Id.

9. PIERRE BERTON, WhY We ACT LIKE CANADIANS 17 (1987). The author responds to a purportedly average American who, upon visiting Canada, asks typical questions that indicate to the author (through ignorance of the Canadian experience) that Canadians "are a different people." Id. at 16. See also Annette Baker Fox, Canada In World Affairs, in THE 
This perceived lack of individuality is not what Canada intended when it became an independent country in 1867. A popular Canadian creation myth suggests that the Fathers of the Confederation intended to borrow "the best of what their ancestors and neighbors had produced" by combining "French culture, British politics, and American technology. But the plan went wrong, and Canada was left instead with French politics, British technology, and American culture." 10 The implication is clear: even from the beginning, Canada has struggled to maintain a distinct identity. Since 1967, the seminal year in Canada's national self-consciousness, this struggle has grown increasingly controversial and political." The stakes are high, as articulated by Former Heritage Minister Michel Dupuy: "[W]e must bring back culture to the forefront of society's concerns, for it is essential to our identity, to our pride, to our unity and to our independence in international society." ${ }^{2}$ Recognizing this priority, the Canadian government has implemented a host of initiatives, programs, agencies, and regulations designed to promote Canadian creativity. ${ }^{13}$

ACSUS PAPERS (1989). Canada's "post-World War II diplomacy as a middle power demonstrates both the opportunity offered by that status and the constraints imposed by it, such as the frequent inattention of foreign onlookers." Id. at 31. Canada's conduct in foreign affairs is distinguished from other middle powers by two conditions: "(1) the task of living 'distinct from, but in harmony with, the world's most powerful and dynamic nation' and (2) the interest 'to ensure the political survival of Canada as a federal and bilingual sovereign state' ...." Id. Regarding the notion that Canada might as well be part of the United States, see JAN MORRIS, CITY TO CITY (1990). Morris states that this is "pure nonsense" and that

almost nowhere in Canada could I suppose for a moment that I was on American soil. Not only is there the utterly distinct French element, not only are the political and social systems quite different, but the whole temper of life in Canada, its manners, its looks, its values, I think, are unmistakably Canadian.

Id. at xiii. See also Joe Chidley, Millennial Angst, MACLEAN's, Jan. 6, 1997, at 23. Interestingly enough, Maclean's polled readers about issues that will face Canada in the year 2005. In response to whether there will be parts of Canada joining the United States, $29 \%$ say that is unlikely, and $26 \%$ say that is unacceptable. Id. These percentages do not represent the overwhelming majority that might be expected.

10. Manning, supra note 1 , at 3 .

11. The struggle engages a further complication, namely, the limitations of political bodies to comprehend the problem. See BERTON, supra note 9, at 4 (stating that "Americans don't really understand how different we are . . . . [U.S.] leadership doesn't understand it .... What distresses me is the realization that our own government doesn't appear to understand it either.").

12. Amy E. Lehmann, The Canadian Cultural Exemption Clause and the Fight to Maintain an Identity, 23 SYRACUSE J. INT'L L. \& CoM. 187, 188 (Spring 1997).

13. Protection of Canada's "cultural industries" has been accomplished, with undeniable success and continuing controversy, through a variety of governmental initiatives, some of which will be addressed throughout this note. Examples of such measures include cultural industry exemptions in international treaties, the use of content requirements imposed on broadcasters, and, most recently, the extensive revisions of the Canadian Copyright Act. The 
The most recent attempt to shelter the fragile Canadian culture came in the form of Bill C-32, An Act to Amend the Canadian Copyright Act, which was passed by Canada's Senate in April $1997^{14}$ and took effect 1 September 1997. ${ }^{\text {is }}$ These recent amendments to the Copyright Act represent the "most comprehensive attempt at reform of [Canadian] copyright law in 75 years. $" 16$ The world was a vastly different place when the copyright legislation was first established in $1921,{ }^{17}$ and the Canadian Copyright Act has received only minor amendments since that time. ${ }^{18}$ Canada's copyright

catalyst that brought "cultural industries" to the foreground was the debate about various types of free trade, which developed into a remarkable demonstration of unity among Canadians for the protection of their "cultural industries." Lehmann, supra note 12, at 188-89. In general, the United States-Canada Free-Trade Agreement Implementation Act of 1988 (FTA) was designed to promote fair competition by removing trade barriers between the United States and Canada. Id. at 189. Culture became a focal issue in these negotiations, instigated by the government of Ottawa, because of the overall Canadian view that the United States dominates the communications and entertainment industries. Id. at 188. "The FTA was the first free trade agreement to broadly exempt cultural products from its general free trade provisions

. . ." Id. at 189. "Cultural industries, as defined in the FTA, include the publication, distribution or sale of books, magazines, periodicals, newspapers, films, video recordings, audio or visual music recordings, and music in print, as well as radio, television, cable, and satellite broadcasting services." Id. at 189.

14. Performers Cheer Final Passage of Copyright Bill, CANADA NEwsWIRE, Apr. 25 , 1997.

15. Ross Mutton, Status of Bill C-32, an Act to Amend the Copyright Act (visited Nov. 24, 1997) <http://ccins.camosun.bc.ca/ amtec/c32forc1.html >. The Heritage Department was principally responsible for this reform.

16. Howard P. Knopf, Canada's Copyright Law Gets an Overhaul: There are plenty of winners and losers under the federal government's new Bill C-32. FIN. POST, May 25, 1996 , at 1 .

17. See Bernard Grun, The TImetables of History 478 (1991). For historical perspective, Gandhi was emerging as India's leader in its struggle for independence, and the $18^{\text {th }}$ Amendment to the U.S. Constitution had just gone into effect. Id. at 478-79.

18. But this was not for a lack of trying. See JAN MATEJCEK, HISTORY OF BMI CANADA LTD. AND PROCAN: THEIR ROLE IN THE FORMATION OF SOCAN 44 (2d ed. 1996). After many years of trying to change the Canadian Copyright Act of 1924, in 1977, two consultants to the Department of Consumer and Corporate affairs released the first revisionoriented publication entitled Copyright in Canada: Proposals for a Revision of the Law. Id. Hopes vanished quickly because the government did not intend to change the Act, but this publication heightened the pressure for change, as did the increasing international successes of Canadian composers and performers. In 1982, the final report by the Federal Cultural Review Committee was released, which said "the artistic profession must be placed on the same footing as any other honorable and vital vocation. When creative artists, and what they create, receive recognition and esteern commensurate with their contributions to our community and culture, much else will follow." Id. at 71. As copyright reform became a focus of PROCAN (Performing Rights Organization of Canada), it was also a dominant theme at the 1982 Rome Congress of CISAC "when a report called The Price of Copyright, presented by SACEM, the French Performing rights society, was discussed." Id. The report showed that the percentage of musicians who can live off their royalties was below $10 \%$ and only $4 \%$ (of 87,000 persons sampled) "received the average minimum salary of countries surveyed." 
reform was indeed a response to recent technological advances that are forcing the entire world to revise outgrown copyright laws, especially in relation to issues presented by the internet and digital reproduction. ${ }^{19}$ Because copyright law generally reacts to technology, and consequently is behind it, the timeliness and necessity of copyright reform in Canada can hardly be questioned. ${ }^{20}$

This note focuses on the recent establishment of "neighboring rights"21 in the Canadian Copyright Act through Bill C-32. ${ }^{2}$ A form of derivative copyright protection benefitting various contributors to a work, neighboring rights were created to protect Canadian culture. However, these rights may actually hamper cultural development by imposing increased copyright fees on Canadian radio-a medium that has played a crucial role in promoting Canadian culture. ${ }^{23}$ Part II of this note examines the distinct qualities of

Id. Promises of a new Copyright Act emerged again in 1984 through a "White Paper," From Gutenberg to Telidon, which originated in two departments-the Department of Consumer and Corporate Affairs and the Department of Communications. Nothing tangible came of it. Id. at 79 .

19. See Rebecca F. Martin, The Digital Pefformance Right in the Sound Recordings Act of 1995: Can it Protect U.S. Sound Recording Copyright Owners in a Global Market, 14 CARDOZO ARTS \& ENT. L.J. 702 (1996). The "growing recognition that new digital technologies threaten to displace the traditional methods of sound recording distribution" and "the United States' desire to establish sufficient protection in an expanding global market" led to The Digital Performance Right in Sound Recordings Act of 1995. Id. See also Barbara Waite, Communications and Copyright in Canada and the U.S.: A Survey of Current Law and Proposals for Change, 1 TRANSNAT'L LAw. 121 (Spring 1988).

20. See generally S.M. STEWART, INTERNATIONAL COPYRIGHT AND NEIGHBOURING RigHrs (2d ed. 1989). Advances in technology communication set the pace for copyright laws the world over because "pirates set the speed their pursuer must take if they are to be caught." Lord Scarman, Foreword to STEWART, supra at v. Cf. Prudence Adler, WIPO: Summary and Key Accomplishments (visited Nov. 24, 1997) <http://arl.cni.org/newsltr/192/wipo.html >. The internet is currently the single greatest culprit in wreaking havoc on copyright systems, forcing many changes and reforms. Witness the WIPO treaties, primarily initiated to address copyright problems relating to the internet. Id.

21. "Neighboring rights" extend copyright protection-traditionally available only to the author of a work-to performers, musicians, producers, and other creators and contributors. See infra text accompanying notes $130-41$ for a more detailed explanation of neighboring rights.

22. See Michael McCabe, Speaking Notes from Insight Conference on Copyright Reform, May 30, 1996, in Paying Twice for the Same Goods (visited Jan. 25, 1998) <http://www.cab-acr.ca/Insight_MM.htm>. McCabe refers to the intense debate that surrounded Bill C-32 and expresses the idea that "[i]n the popular parlance [the discussion of neighboring rights] often ends up being a battle between broadcasters and creators." Id.

23. This note will focus on private Canadian radio stations, as distinguished from the governmental Canadian Broadcasting Corporation ( $C B C)$. The neighboring rights provisions in the copyright amendments will have the most severe impact on the private stations. Despite increasingly drastic cuts in $\mathrm{CBC}$ funding, the threat of financial burdens caused by the copyright amendments are more threatening to privately owned stations. See KNOWLTON NASH, THE MICROPHONE WARS 550 (1994). Although private broadcasters have improved 
Canadian music and the role of radio in promoting Canadian musicians. It also explores some of Canada's reasons for attempting to protect the country's culture from bombardment by U.S. influences. This section explains how radio plays an integral role in developing new artists and, therefore, culture itself. ${ }^{24}$ Part III turns to the neighboring rights provisions of the copyright amendments. ${ }^{25}$ Included is a brief overview of Canada's approach to copyright law in general, the procedural changes that the amendments created, and the political posturing that impacted the shape and timing of the amendments. Part IV offers reasons why the objectives of the copyright amendments will not be met and proposes some suggestions to remedy the problem. For example, in addition to imposing economic hardship on struggling radio stations, the neighboring rights provisions will fail to help the artists they were intended to benefit. As a result of the amendments, only the most successful Canadian artists will earn extra income from the performers' rights provision. In short, by paralyzing the private radio industry, the new copyright amendments threaten to backfire on Canadian artists and the nation itself.

\section{The Role of Music and Radio in Defining Canadian Culture}

The CEO of the Recording Industry Association of America recently told a joke on a Canadian radio show: "What's the difference between yogurt and Canada? Yogurt has an active culture. ${ }^{\text {26 }}$ While Canadians are generally good humored and can accept a healthy dose of self-deprecation, this joke reveals a damaging, yet all too common, misconception of Canada. ${ }^{27}$ The definition of "culture" suggests that much is at stake when a nation's culture is threatened. Culture is "the totality of socially

their Canadian programming in recent years, their decisions will always be limited by profit considerations. As a taxpayer-supported body, the CBC's bottom line is public service. Id.

24. Naturally, much more than music and radio contribute to a culture, but this note is limited to these factors because of their particular contributions to Canadian culture.

25 . The recent amendments will affect many groups not covered in this note. These groups include students, educators, and booksellers, each with respective concerns about how the copyright amendments would restrict the purchase of used textbooks, increase the cost of photocopying coursepacks, and prevent the importation of foreign books without authorization. Opinion, Cracks in Liberals' Copyright Bill, FIN. POST, Apr. 26, 1997. See NORMAND TAMARO, THE 1997 ANNOTATEd CopYright ACT (Christopher McGuire trans., 1996). Another bill, C-307, amended the Criminal Code and the Copyright Act. Id. at xxix. Bill C307 was not associated with neighboring rights, but it does grant the Crown profits from authorship that accrue to a convicted person or his family. Id.

26. Carlson, supra note 6 , at n. 188.

27. The cultural impact is largely internal (within Canada) and "goes all but unnoticed in the United States." DICKEY, supra note 2, at X. Persistent article titles such as Mike Mettler's Everybody Thinks This Is Nowhere: Canadian Rock Is Alive and Well. But Will It Pass Customs? certainly aggravate matters. GUITAR, Nov. 1997, at 48-59. 
transmitted behavior patterns, arts, beliefs, institutions, and all other products of human work and thought. ${ }^{28}$ The secondary meaning of culture broadens to include "intellectual and artistic activity, and the works produced by it." 29 From Latin, by way of Middle English, "culture" derives from "cultivate," which means "to improve and prepare; to promote the growth of; to nurture; to form and refine." 30 Thus, a biological metaphor emerges: culture is capable of being grown. Accordingly, it is not only understandable but also essential that the Canadian government take action to nurture its delicate culture..$^{31}$

The circumstances surrounding Canada's origins help to explain Canada's problem of maintaining a cultural identity distinct from that of the United States. British Loyalists moved north as a result of the American Revolution; Canada was founded in 1867 to avoid being assimilated into the United States. ${ }^{32}$ The fundamentally different organizing principles upon which each country was founded have generated widely divergent social impulses. "The United States adopted Whig values of . . . liberal democracy and laissez-faire economics, . . . embraced an ideological understanding of its national identity . . . , and carried the Reformation to its social conclusion by embracing sectarian Protestantism as a popular but strictly 'unofficial' religion." 33 Canada, however, accepted

Tory values of monarchy and hierarchy, adopted the concept of public political responsibility for economic management and social well-being, embraced a pragmatic, historically conditioned, and compromised sense of national identity rather than an ideological or vocational one, and remained loyal to the Catholic and denominational Protestant churches, allowing them a formal and state-supported relationship to secular society. ${ }^{34}$

Beyond this philosophical separation from the United States, until the early 1900s Canada was geographically cut off from the world. Cultural activities

28. The American Heritage Dictionary 454 (3d ed. 1992).

29. Id.

30. Id.

31. There is no question that culture is essential to the survival of a civilization. In addition to the classical antecedents such as Plato's Republic (where a philosopher-king ruled) or Gibbon's commentary on the Roman Empire, Toynbee's cyclical theory of history, Mumford's Technics and Civilization, and the writing of Canada's media guru, Marshall McLuhan (especially in The Medium is the Message and Understanding Media) exemplify this point. Martin Segger, THE CANADIAN ENCYCLOPEDIA, supra note 1, at 1277-78.

32. Lehmann, supra note 12 , at 192.

33. Manning, supra note 1 , at 25.

34. Id. at 25-26. 
depended on the talents of local residents..$^{35}$ Canadians "participated" in culture, so to speak, by singing in church or attending concerts by amateur performers at private parties. "Only the wealthiest" members of society "could afford to buy books or hire musicians to play at parties," and the "elite joined lecture clubs, poetry circles, and reading groups." 36 Despite this class-based inequity, it is clear that even from the beginning, listening to musical performances was often an intimate, communal activity reflecting, and contributing to, the collectivist view Canadians held. ${ }^{37}$

By 1967, Canada's centennial year, interest in strengthening the Canadian image swelled. The occasion was a well-spring for national pride. Boosted by the success of the Montreal World's Fair, Expo '67, the Centennial spurred tremendous growth in Canada's cultural industries. Canadian publishing experienced a renaissance, through the expansion of the paperback New Canadian Library and the new eighteen-volume history, The Canadian Century Series, as well as through best-selling authors like Pierre Berton, Farley Mowat, Irving Layton, Mordecai Richler, and through the emergence of several new publishers..$^{38}$ Musically, many works by Canadian composers were commissioned for the Centennial by the Canada Council, and by various cities, municipalities, and performing organizations. ${ }^{39}$

Unfortunately, these efforts to foster national pride (as well as the Centennial itself) were undermined in subtle ways, as evidenced by Canada's failure to adopt the country's national flag (the red maple leaf between two red bars) until 1965, ninety-eight years after confederation. ${ }^{40}$ The irony of a one-hundred-year-old nation largely indifferent to its two-year-old flag was significant because a national flag is typically unparalleled at generating "learned responses to an evocative national symbol." ${ }^{\text {41 }}$ Furthermore,

35. K. Marie Stolba, The Development of Western Music: A History 620 (1990) ("The centers of musical activity were the local church, the coffee house, and, in larger communities, the military band.").

36. Lehmann, supra note 12 , at 193.

37. These wholesome communal values are celebrated in the humorous Mariposa stories of the economist-author Stephen Leacock. See SUNSHINE SKETCHES OF A LITTLE TOWN (1912).

38. James Marsh, Book Publishing, English-Language, in THE CANADIAN ENCYCLOPEDIA, supra note 1, at 248-49.

39. MATEJCEK, supra note 18 , at 13.

40. JAMES L. HALl, RAdio CANADA INTERNATIONAL: VoICE OF A Middle Power 2 (1997). Northrop Frye commented that Canada is "the only country with a vegetable device as its national symbol." John Ross Matheson, Flag Debate, in ThE CANadian ENCYCLOPEDIA, supra note 1, at 502. The debate involved proponents of the British Union Jack design and those supporting a red ensign that would honor British and French traditions. The 23-point sugar maple leaf was adopted by Royal Proclamation under Queen Elizabeth II on 15 February 1965.

41. HALL, supra note 40 , at 2. 
Canada's Constitution remained in England until 1981..$^{42}$

Despite some of the cultural ironies surrounding the Centennial, Canada's national identity has continued to emerge. Indeed, from 1982 to 1994, cultural growth in Canada occurred more rapidly than in the past century: in 1982, for example, 352,000 Canadians worked in the cultural industries; by 1994 , the number had grown to $660,000 .^{43}$

Given the vast philosophical and historical differences between Canada and the United States, it would be surprising if a unique and vibrant Canadian voice had not developed. Nevertheless, defining Canadian culture precisely is impossible because of the ineffable and amorphous nature of culture itself. Perhaps the closest thing to a definition is the elusive statement that "there is not one Canadian culture, but many. "44 Canadian culture, then, is ethnicity in its plural expression; it is the "symbolic total of what the country's ethnic collectivities choose to reveal about themselves through a plethora of media and community events that tourists visit, scholars study, and politicians patronize. ${ }^{\text {/S }}$ Still, these factors at times seem to combine to form an uncertain, ironic, ambivalent, and self-contradictory identity. ${ }^{46}$

In procedure and substance, Canadian popular music reflects the various elements that contribute to the divergent Canadian identity. In the same way that most American music is derivative in nature, ${ }^{47}$ Canadian music has imported American genres as well as the general American "proclivity for musical syncretism and eclecticism." 48 This has led to unlikely loyalties: American blues artist Lemon Jefferson has a devoted fan base in Newfoundland, while the Ink Spots "stir the souls of Saskatchewan wheat farmers." "American, Cajun, and French music have been syncretized in Quebec, for example, while country music from the United States has been mixed with Anglo-Irish folk music to make what entertainers

42. The British North America Act, enacted by British Parliament in 1867, provided for confederation and was renamed the Constitution Act of 1867 in 1981 as part of the movement toward "patriation" of the Constitution, which included bringing the Constitution home from Westminster, England, to Ottawa, Canad.

43. Lehmann, supra note 12 , at n.52.

44. Manning, supra note 1 , at 6.

45. Id.

46. David H. Flaherty, Preface to BEAVER, supra note 1, at xii.

47. Jazz is often cited as the only truly American art form. Of course, jazz also exhibits international derivations, developing from the "complex polyrhythms of African tribal music and the call-response nature of musical performance in African societies." STOLBA, supra note 35, at 798. Jazz also borrowed from "spirituals, gospel songs, secular songs dealing with personal situations and feelings, blues, cakewalk, and ragtime." Id.

48. Manning, supra note 1 , at 20.

49. Id. 
call the "Newfoundland Sound." "home-grown" country music industry. Canadian country performers have been popular in the United States since the 1930s, reversing the direction of the usual cultural flow and thus "contributing Canadian content to the eclectic repertory of American popular music." 51

Like Canada itself, Canadian popular music is distinguished by contrasts, contradictions, regional peculiarities, and collective synergies. "Ingrained in our music is the sound of waves crashing on craggy shores, tuned to the roar of Cape Breton coal mines," writes one Canadian music critic. $^{52}$ Everything from bar-blues to visionary songwriting to kids in garage-bands reflects the "mix of primal and sophisticated international flavors introduced by [Canada's] multicultural makeup. ${ }^{\text {} 53}$ One explanation for the depth and variety of Canadian popular music, in language echoing psychologist Carl Gustav Jung's theories on the collective unconscious, ${ }^{54}$ is that "subconscious elements of these multiple environments and inheritances are somehow transfused at birth to all, distilled through characteristic Canadian restraint." 55 And while Canadian popular music reflects an undeniable attraction to the "larger-than-life, instantly disposable American dream," it is balanced by "formal British reserve and classicism, a devotion that can flare with francophone passion and impulsiveness when sufficiently provoked." 56

Private Canadian radio stations play a significant role in promoting Canadian musicians. Private radio has been called "Canada's \#1 talent agent," $"$ although the total revenue of the private radio industry equals only

50. Id. at 20-21.

51. Id. at 21. This suggests that Canadian music may be a secret weapon of sorts in Canada's defense against the U.S. onslaught. As early as 1954, BMI Canada hired song pluggers to promote Canadian songs in the United States. By 1972, BMI Canada launched the "Maple Music Junket" which was "aimed at the overseas media and music industry representatives in order to give them a chance to meet and hear the individuals and groups who helped create the booming Canadian music scene." MATEJCEK, supra note 18, at 29 . These concerts were held over four day periods in Montreal and Toronto and involved European guests from fifteen countries. Id.

52. Roch Parisien, Collections Celebrate Canadian Culture (visited Nov. 30, 1997) <http://www.taponline.com/tap/music/reviews/roch/0209.html > .

53. Id.

54. See generally C.G. JUNG, MEMORIes, DREAMS, Reflections (1989). See also infra text accompanying notes 232-37.

55. Parisien, supra note 52.

56. Id. Parisien characterizes Canadians as "polite party animals with a social conscience." Id. This image, if not created by, was sustained and immortalized by Canada's Bob and Doug McKenzie, one of the most famous sitcom duos on the North American continent. Their most famous skit involved "two 'hosers' in front of a map of Canada talking about beer and hockey." Lehmann, supra note 12, at 201.

57. Canadian Association of Broadcasters, Private Radio Music Awards to Boost New 
about half the operating costs of the public Canadian Broadcasting Corporation (CBC). ${ }^{58}$ Beginning with station XWA in Montreal in 1920, radio broadcasting quickly became the dominant carrier of entertainment, news, music, and cultural values for the densely populated areas of Canada. ${ }^{59}$ From the very beginning, Canadian radio was intended to promote unity and to encourage cultural development and awareness. ${ }^{60}$ In 1937, Canada began planning its entrance into shortwave radio broadcasting in order to enhance national prestige, foster international goodwill, and project Canadian culture. ${ }^{61}$ With many of the same goals as Radio Canada International (RCI),

Canadian Talent (visited Jan. 24, 1998) <http://www.cab-acr.ca/newsrel97.htm> [hereinafter $C A B$ Press Release]. This distinction is due in great part to Prime Minister Diefenbaker, who changed the idea of a single Canadian broadcast system consisting of a dominant public broadcaster and merely supplementary private broadcasters. NASH, supra note 23, at 268 . He thought that the Canadian Broadcasting Corporation (CBC) "indiscriminately embraced North American continentalism and could not differentiate between American national opinion and true internationalism." Id. at 266-67. Thus, in 1957, he introduced a broadcast bill establishing two boards. The first was regulatory in nature, giving equal status to private stations and the CBC alike. The second ran the CBC. As a result, the $\mathrm{CBC}$ annually had to petition Parliament for money. The bill thus tightened governmental control of $\mathrm{CBC}$ operations, beginning a nightmare of long-range programming plans that propelled the CBC into "the most tumultuous era in its history." Id. at 269.

58. Michael McCabe, Opening Statement Before the House of Commons Standing Committee on Canadian Heritage Hearing Respecting Bill C-32, an Act to Amend the Copyright Act, Oct. 8, 1996 (visited Dec. 3, 1997) < hup://www.cab-acr.ca/statement_C 32.htm > [hereinafter CAB Opening Statement].

59. HALL, supra note 40 , at 3. Radio Canada International (RCI) was similarly formed with the programming goal of protecting Canadian identity and a pledge to represent all of Canada. Id. at ix-x. RCI interpreted Canada to the world radio audience "through broadcast topics that reflect[ed] elements of Canadian life in the form of news, features, and entertainment." Id. Musical programs were an original staple of daily programming. One program, "Concert from Canada," was a half-hour recital featuring Canadian instrumentalists and vocalists. Id. at 38. Complaints of too much music on the radio soon followed. NASH, supra note 23, at 42. An October 15, 1924, Maclean's article, How Can Radio Be Best Utilized to Inculcate National Ideals and Foster National Unity?, said that "thousands of fans . . . want something more than an orchestra from their loud speaker. They want news stories ... talks on science, politics, religion .... They do not want every station in the country at all hours to be broadcasting nothing but ... music." Id.

60. As an historical aside, it was a Canadian who accelerated radio technology beyond encrypted Morse Code messages. On December 23, 1900, the first transmission of intelligible speech by electromagnetic waves was accomplished by a Quebec-born inventor named Reginald Fessenden, who was working for the U.S. Weather Bureau at the time. NASH, supra note 23 , at 25 .

61. HALL, supra note 40 , at $x$. The need was real because Canada was often inaccurately perceived, as a quote from a German prisoner demonstrates:

Due to the . . . isolation of life in the Third Reich, and due to the strongly propagandistic publications in Germany about foreign countries, 1 had al ways imagined Canada to be the dead end of the world. How surprised I was when I saw modern limousines rushing over smooth roads, instead of the trapper 
Alan Plaunt and Graham Spry formed in 1930 the Canadian Radio League, the early incarnation of the CBC. ${ }^{62}$ Espousing the motto "Canadian radio for Canadians," these men believed radio could be the greatest of all Canadianizing instruments, since radio could be an educational vehicle, a model for experiments in the conduct of public business, and even the beginning of a larger social revolution. ${ }^{63}$

Similar ideals and objectives are sustained in the current Broadcasting Act. The broadcasting policy was designed to nurture Canadian expression "by providing a wide range of programming that reflects Canadian attitudes, opinions, ideas, values, and artistic creativity, by displaying Canadian talent in entertainment programming and by offering information and analysis concerning Canada and other countries from a Canadian point of view. ${ }^{n 64}$ The Act also requires that the programming "should be of high standard. "65

Radio brought high hopes for unifying the massive Canadian territories, as the optimism of RCI, the Canadian Radio League, and the Broadcast Act suggests. Radio offered unparalleled potential for "information dissemination, generated new communications channels crucial to nation building, and increased awareness of the political processes among the populace. ${ }^{n 6}$ However, the pervasive radio broadcasting ultimately

cutting his way through the virgin forest with a bush knife! And how thoughtful I became when I realized that I, a German worker, allegedly the best paid worker in the world, had barely been able to afford a bicycle, while here in Canada lots of workers own cars and think nothing about it.

Id. at 29. In a modern context where multi-media entertainment forms have increased the competition in radio's market, it is easy to underestimate the significance of radio in these times. The fact that Hitler placed enormous emphasis on foreign broadcasts, having decreed the death penalty for listeners of foreign broadcasts, demonstrates the influence radio was once believed to wield. Id.

62. NASH, supra note 23, at 22. Spry and Plaunt knew that Canadians listened to American radio programs $80 \%$ of the time, and they thought that this was a "cancer eating into the Canadian sense of nationhood." Id. at 21. They also "abhorred the insistent, ceaseless hucksters [selling soap], laxatives, and toothpaste on the radio" and the prevalence of programming aimed at the lowest common denominator. Id.

63. Id. at 22.

64. Broadcasting Act of 1991, ch. 11, § 3(d)(ii), 1991 S.C. 117 (Can.), in Carlson, supra note 6, at $623 \mathrm{n} .157$. This language has been maintained since its adoption in 1968. While more focused, the language of this Act obviously reflects the early objectives of Canadian broadcasters.

65. Id. $\S 3(\mathrm{~g})$. The Broadcasting Act is likely to be amended soon. The bill, entitled "Canadian Voices: Canadian Choices," provides new broadcasting policies and "requires that the government spend $\$ 210$ million over four years to achieve the policy goals." See Lehmann, supra note 12, at 196. "Canadian Voices: Canadian Choices" was propelled by the failure of the Canadian broadcasting bill of 1988 , Bill C-136, which suffered a political death due to the 1988 general election. Id. Bill C-136 was "intended to ensure that audiences were offered a wide range of programming." Id.

66. HALL, supra note 40 , at 3 . 
offered false hope for Canadian nationalists. "[F]rom the inception of Canadian radio broadcasting, there was the threat of denationalization" because American broadcasts could easily reach the heavily populated Canadian cities along the border. ${ }^{67}$

Perhaps as a result of optimism prematurely deflated, Canadian radio has consistently been plagued by financial instability. ${ }^{68}$ Radio stations were never expected to be able to pay for themselves, but the first attempts at financing radio developed slowly in the 1920 s. $^{69}$ Consequently, the divergent financial success of Canadian stations followed an obvious pattern: stations surrounding densely populated metropolitan areas prospered, while those in sparsely populated regions floundered. "The lack of adequate geographic coverage of Canadian broadcast programming" created tension between the government and the public. ${ }^{70}$ The reality was that while urban areas received Canadian programming, much of the population heard only American stations.

The government quickly realized that "[i]f radio broadcasting was to foster national unity, the large numbers of people living across rural Canada needed access to Canadian radio stations. ${ }^{n 11}$ In order to study the radio broadcasting situation throughout Canada, the House of Commons spent $\$ 25,000$ in 1928 to explore the future management and financing of radio stations. ${ }^{2}$ As a result, Parliament passed the Canadian Radio Broadcasting Act (1932) and established the Canadian Radio Broadcasting Commission $(\mathrm{CRBC}){ }^{73}$ The $\mathrm{CRBC}$ operated under an astute principle: "broadcast frequencies were a 'scarce public resource,' and all broadcast licenses are 'a temporary monopoly, to be operated as part of a single national system in the

67. Id. These men foresaw the cultural invasion of Canada by American values, American performers, and American stories. They believed if Canadian radio could offer an exciting alternative, it would win over the fans of American programs. While Spry and Plaunt were specifically working toward shortwave international broadcasting, their views nonetheless reveal the high expectations held for broadcasting. Id. at 21 .

68. See infra notes 176-77, 215-16 and accompanying text.

69. HALL, supra note 40 , at 4 . Most of the first radio stations were owned by newspapers or firms selling radio equipment. Perhaps this was a response to predictions of printed newspapers becoming obsolete in the wake of radio. More likely, publishers wanted to promote their newspapers or feared furure competition for advertising revenue. Newspaper radio station owners did not support the idea that the new medium should be supported solely by advertising. "[T] since the Americans had 'free radio." The first Canadian attempt to finance the new medium was termed 'indirect advertising,' and followed the American model." Id.

70. Id. at 5.

71. Id. at 5 (footnote omitted).

72. Id. at 6 .

73. Id. at 7. The CBC replaced the CRBC four years later in 1936. NASH, supra note 23, at 16 (discussing major Canadian radio developments). 
public interest.' 74 This principle became the foundation for subsequent Canadian broadcasting legislation.

Although private radio lost an estimated $\$ 180$ million in the first half of the $1990 \mathrm{~s},{ }^{75}$ Canadian radio is nevertheless extremely popular and is an important vehicle for fostering Canadian culture. Throughout Canada, private radio stations provide free local services (news, weather, sports, public affairs, and music selected for targeted audiences), and the programming is better suited for the immediate listening area than are the CBC satellite broadcasts. That these stations fill a need is evidenced by the fact that radio listening has been steadily increasing in spite of many new entertainment choices. Studies have consistently confirmed the critical role radio plays in promoting Canadian culture, especially pertaining to consumer music purchases. In May of 1997, the Angus Reid Group conducted an independent survey of 1000 Canadians who bought a CD, tape or record in a six month period. ${ }^{76}$ Radio, as the number one factor influencing these purchases, outscored the next biggest factor, television-with its music video channels-by three to one. ${ }^{\pi}$ This confirmed a Quebec study conducted by the music industry in 1993 and 1994, and yet another study conducted by Decima Research, which focused on teenagers. Both studies revealed radio airplay is the single greatest influence on retail music sales. ${ }^{78}$

Still, radio cannot take all the credit for promoting Canadian musicians. When BMI Canada (an owner and promoter of a vast repertoire of music) started in 1947, Canadian music was rarely recorded or published, much less played on radio. The Canadian branches of U.S. recording companies were not interested in Canadian product, and the few "Canadian companies that existed were mostly unwilling and unable to take chances on local talent. ${ }^{79}$ By 1951, BMI Canada's publishing and promotional efforts led to the launch of the BMI Pin-Up Sheet (Yes, there IS Canadian Music), which provided radio stations with a list of recorded popular music by Canadians, followed by The BMI Canada Newsletter, which gave news about BMI affiliates and their activities. ${ }^{80}$ Other publications also sprang up to

74. HALL, supra note 40, at 7 (footnote omitted).

75. Ashley Geddes, New Royalties Spur Disharmony Between Artists, Radio Stations, EDMONTON J., Oct. 29, 1996.

76. Jane Logan, CAB Opening Statement, supra note 58. This should not be interpreted as an indication that Canadian music video channels are not viable. See Joel Stein, The M Is Back in MTV, TIME, Dec. 1, 1997, at 103. In the United States, the popularity of MTV has been waning. MTV used the Canadian equivalent of MTV, MuchMusic, as a model for restructuring its lagging programming.

77. CAB Opening Statement, supra note 58.

78. Id.

79. MATEJCEK, supra note 18 , at 16.

80. Id. at 18. 'Composers of 'serious music' received direct and indirect benefits from the Canada Council, while the Canadian Music Centre provided a library and information 
promote Canadian music. The trade magazine $R P M$ reported on the fledgling Canadian music industry through articles, reviews, and surveys. CAPAC's (Composers, Authors and Publishing Association of Canada) The Canadian Composer and BMI Canada's The Music Scene were also helpful in promoting the writers, composers, and publishers of their respective organizations.

Nevertheless, the effect of all these efforts, even when measured in the aggregate, could not keep pace with the efforts of U.S. entertainment companies to promote their own artists. Canadians, like many other peoples, seek out American culture. Visiting the United States is part of the Canadian experience, and statistics reflect the enormous impact of cross-border travel on Canadians. Over " $85 \%$ of the foreign trips made by Canadians are to the United States. "81

The bigger problem is that U.S. entertainment industries have thoroughly saturated the Canadian market. For example, “63\% of Canadian television viewing time is spent watching non-Canadian programs, primarily programs from the [United States]," and the figure rises to eighty-five percent in the area of drama; eighty-two percent of all newsstand periodicals sold in Canada originate from foreign countries, mostly the United States. ${ }^{82}$ The exception appears to be the medium of radio. Canadians appear to prefer Canadian radio stations over the U.S. stations, which are equally accessible. ${ }^{83}$

While it is difficult to determine the exact nature of the loyalty to Canadian radio stations, there can be no doubt that the decision by the Canadian Radio and Television Commission to adopt Canadian content regulations has had an enormous impact on the Canadian music industry. ${ }^{84}$

services from 1959." Id.

81. Manning, supra note 1, at 22. Thus, mass tourism is a vehicle of American cultural hegemony. "For years, half the British emigrants who went to Canada" hoped to reach the United States. MORRIS, supra note 9, at xii. Morris recollects being told by a Turk in the 1970s that "if you lived to a ripe old age in Canada you died of boredom." Id.

82. The Honorable Donald Macdonald, The Canadian Cultural Exemption Under Canada-U.S. Trade Law, 20 CANADA-U.S. L.J. 253, 254 (1994). Macdonald served as a Canadian High Commissioner to Great Britain and Northern Ireland in the early 1990s. Id. at 261 n.a.

83. Id. While other factors contribute to this loyalty, it is unquestionably due in part to comparative quality. The cost of making television shows has increased dramatically (because of actors demanding higher salaries, viewers demanding movie-quality special effects, etc.). The dollar expense to meet such demands is no less in Canada, but, with only a fraction of the U.S. population, the chance to turn a profit on the investment is small. Conversely, the cost of producing commercial quality music has dropped dramatically as technology has made digital quality recording equipment affordable even to amateur musicians. Thus, musical competitiveness more accurately reflects talent, and there is no question that Canadian musicians rival those from the United States or any other nation.

84. See MATEJCEK, supra note 18, at 24. 
The Canadian content rules, specifically the restrictions on foreign ownership and on broadcast content, are considered the most important policies that the Canadian Radio-Television and Telecommunications Commission (CRTC) has implemented to protect Canada from American entertainment. ${ }^{85}$ Essentially, radio is required to play Canadian artists thirty percent of the time. ${ }^{86}$ These minimum requirements are widely regarded as the key to the success and growth of the Canadian music industry. Without the content laws, Canadian performers competing with those of the United States might never have found the opportunity to demonstrate their talents. Since the establishment of the content laws, "Canadian popular music groups have been highly successful." ${ }^{87}$ The Minister of Heritage explicitly recognized that the Canadian music industry has blossomed and developed a critical mass of artists, primarily because of Canadian content rules. ${ }^{88}$

However, the Canadian content rules, like more recent efforts to protect Canadian culture, have not been well-received in the United States. ${ }^{89}$ Some have stated that such policies overtly "discriminate against . . . U.S. cultural industries." This argument falters upon recognition that Canada's cultural policies do not block American books, magazines, records, programs, and movies from entering Canada; such policies "would be impossible as well as foolish." 91 The policies simply ensure a place in the

85. Id. The CRTC issues broadcast licenses and oversees Canada's centralized communications network, including the CBC.

86. Carlson, supra note 6 , at 588 . "Sixty percent of all programming and $50 \%$ of all prime time programming must be of Canadian origin." Id. Until recently, Canadian television and radio stations had to be at least $80 \%$ Canadian owned. Id.

87. Macdonald, supra note 82, at 263. Of course, the content rules benefit more than just musicians. One may wonder how writer Stephen Leacock would have fared with help from content rules. In order to get published, he wrote as an American because the American market was not prepared to accept an obviously Canadian writer.

88. CAB Opening Statement, supra note 58.

89. See supra note 13.

90. Hale E. Hedley, Note, Canadian Cultural Policy and the NAFTA: Problems Facing the U.S. Copyright Industries, 28 GEO. WASH. J. INT'L L. \& ECON. 655, 655 (1995). The author of that note asserted that through an exemption negotiated by the Canadian government in NAFTA, "Canada is able to discriminate against corresponding U.S. cultural industries for any reason without being subject to the NAFTA enforcement procedures." Id. See also Lehmann, supra note 12 , at $188-89$ " The inclusion of the cultural exemption clause created minimal controversy but became subject to definitional and explanatory refinement in future negotiations for the North American Free Trade Agreement."). See also Carlson, supra note 6 , at 598. Without diverging into a NAFTA analysis, such protests reveal an almost tyrannical quest to monopolize Canada's entertainment industry. Furthermore, the United States has five distinct ways to combat Canada's protectionism under NAFTA: "the GATT/WTO system, NAFTA/FTA, section 301, a lawsuit in Canadian court, and an independent private action." Id. 
market for Canadian books, magazines, television shows, and movies.92 Such allegations-that Canada is discriminating against the United States-expose a lack of respect and sensitivity for Canada's need to maintain a cultural identity. Many Canadians believe "that Americans are bringing their bulldozers into Canada and running over every regulation that protects Canadian culture."93 For example, while some have called Canada's NAFTA exemption a "virus that needs to be stamped out," offered the more complicated proposition that Canada's efforts at cultural protectionism are motivated by a "hidden agenda that is more economic than cultural." The Canadian response to such allegations is that "if somebody insisted on getting $100 \%$ of the market here in the U.S., he would be sued for antitrust," yet the United States feels it is being treated unfairly. ${ }^{96}$ While the debate over cultural exemptions is sure to continue, the general position of each side seems clear: for the United States, it is economic interests that are at stake; for Canada, it is the right to foster a national identity. ${ }^{97}$

Regardless of the cultural exemptions controversy, there is no question that a distinctively Canadian voice resounds with the strains of a unique people and a national heritage that are decidedly its own. And perhaps the Canadian voice is more vibrant than commonly believed, considering what the National Director of the Canadian Conference of the Arts Keith Kelley recently stated: "One thing everybody forgets is that it has taken us only fifty years to come to this level of cultural development." 98

The Canadian government is working to ensure that its "own tender shoots of art and imagination and individuality are not extinguished." 99 One

92. The need is real; U.S. domination of cultural products in Canada has resulted in a cultural trade surplus for the United States of about $\$ 1.5$ billion. Id.

93. Lehmann, supra note 12 , at 199.

94. Id. at 202 (footnote omitted). Advocates of Canadian culture argue that Canadian entertainers such as Rick Moranis, Jim Carrey, Dan Akroyd, and Michael J. Fox owe their success to the Canadian policies. Id.

95. Id. at 206 (footnote omitted).

96. Macdonald, supra note 82, at 265. Macdonald's agitation was evident as he continued, "[g]iven the percentages, I think Hollywood should stop whining. Go back and tell [your] . . . President that from me." Id.

97. Id. See also Ostry, supra note 3, at 38 (The "modest flowering" of Canadian imagination and Canadian heritage is attributable to the combined efforts of the Canada Council and provincial arts councils, the CBC, TVOntario, provincial educational broadcasters, Telefilm Canada, the National Arts Centre Orchestra, national museums, and parks. American "companies already have their 70 and 80 and 90 percent, and unless they can get one hundred percent they cry foul! Restrictive practices! Unfair! Canadian cultural sovereignty cannot exist under these conditions.").

98. Lehmann, supra note 12 , at 193 . While the point is clear, culture clearly did not wait for governmental approval to start developing. Surely it began when the first creation of music, poetry, or painting was inspired by some part of the Canadian experience.

99. Ostry, supra note 3 , at 40. 
writer eloquently builds on a recurring theme in Malcolm Lowry's novel Under the Volcano-involving a sign in a public garden that reads: "You like this garden which is yours. See that your children do not destroy it"-by elaborating: "In our own bush garden (as Northrop Frye has called Canadian literature), there are weeds blowing in on the wind, there are bugs, there are caterpillars. It may look just like an American garden, but it is Canadian. We should see that our gardeners do not destroy it." 100

Radio performs a public service much more profound and far-reaching than merely providing news and playing music..$^{101}$ As former Minister of Communications Flora MacDonald recognized, radio is much more than just a source of entertainment or a national pastime:

It is of fundamental importance to our political and cultural sovereignty that our broadcasting system be an accurate reflection of who we are, of how we behave, of how we view the world .... It plays a major role in defining our national, regional, local and even our individual identities. It is, therefore, much more than just another industry. ${ }^{102}$

Canada must be careful not to inadvertently strangle an industry, through legislation or otherwise, that is an irreplaceable component in supporting Canadian culture.

\section{Canada's Copyright System, Neighboring Rights, AND THE RECENT AMENDMENTS}

The most controversial aspect of Bill C-32, as it made its way through the channels of Canadian government, was that it created "neighboring rights." These rights include a "performance right ensuring that performers, musicians, and owners of rights to a master recording (including record companies) will be remunerated when songs are aired on radio." 103 The recent amendments to the Canadian Copyright Act have two objectives. The

100. Id.

101. STEWART, supra note $20, \S 7.56$. Thus, the international problems encountered by broadcasting organizations (with regard to their rights) are often handled at the diplomatic level or by public international law. On the other hand, copyright is the exercise of a private right. As a result, broadcasting organizations were not concerned about solutions based on copyright in the early days of broadcasting (i.e., the 1930s and 1940s). Id. Consequently, radio not only developed a degree of dependency on government but also enjoyed a close proximity to the government because radio's influence on the government exceeds that of authors, publishers, or neighboring rights owners. Id.

102. Lehmann, supra note 12, at 196-97 (footnotes omitted).

103. Larry LeBlanc, Performance Right Merits Debated Pending Bill Would Create New Airplay Royalties, BILLBOARD, Nov. 16, 1996. 
first objective is "to strengthen Canada's cultural industries"; the second is "to 'modernize' Canada's copyright legislation by bringing it into line with fifty other countries ... . and to achieve 'a level of fairness' by acknowledging the rights of creators to receive recognition and remuneration for the use of their works. " 104 Whether these objectives will be met has been hotly debated. ${ }^{105}$ Neighboring rights ${ }^{106}$ will be costly to radio, and the income generated will rarely reach the artists who are supposed to benefit from the legislation. ${ }^{107}$ Furthermore, the timing and substance of the amendments appear to have been negatively impacted by Canadian politicians and their personal agendas, which may account for some of the complications identified in this note. These provisions seem contrary to the logical assumption (based on the frailty of Canada's culture, as discussed in Part II) that the Canadian government would be reluctant to impose burdens on a medium that develops culture to the extent that radio does. ${ }^{108}$

The use of copyright to promote culture is, in itself, not surprising because "Canada has always used copyright as a broad based economic tool." 109 This "cultural argument" is one of four fundamental theories behind the application of copyright protection. ${ }^{110}$ The premise for this theory

104. Cynthia Rathwell, Copyright Bill C-32-The Broadcasting Perspectivity, Speech at the Canadian Institute Executive Briefing on Amendments to Copyright (June 27, 1996) (visited Jan. 20, 1998) < http://www.cab-acr.ca/CIE_CR_speech.htm>.

105. See also Ostry, supra note 3, at 39 . Referring to these changes, Ostry writes that, while this "legislation is designed to further protect and reward creators in light of technological changes that have occurred since the Copyright Act was adopted in 1924. . . [M] uch more needs to be done to avoid being swamped by U.S. cultural products." Id. (footnotes omitted).

106. Neighboring rights are similar to rights protected by copyright laws and may be, but are not necessarily, protected under a nation's copyright law. Stephen Fraser, The Copyright Battle: Emerging International Rules and Roadblocks on the Global Information Infrastructure, 15 J. MARShall J. COMPUTER \& INFO. L. 759, 769 (Summer 1997).

107. Many groups not discussed in this note will be affected by the copyright amendments. For example, book distributors will be protected from cheaper parallel imports, unwanted remainders, and other forms of competition. Educators will have to pay for teaching-related photocopying (to organizations acting as collectives on behalf of authors and publishers). Consumers of ordinary blank audio tape will have to pay royalties for copying a CD they already own to use in a car or walkman. Also, the millions of dollars raised annually by these changes will leave Canada because there will be virtually no payments in return from the United States. Howard P. Knopf, Bill C-32 and Copyright Reform in Canada: Never Say Never, Presented to Insight Conference (May 30, 1996) (visited Dec. 2, 1997) < http://www.node.on.ca/networking/forums/copyright.html >.

108. One explanation is that the governmental bodies that passed Bill C-32 did not understand music industry practices. The provision of neighboring rights is intended to help performers, not hurt radio. Unfortunately, it is likely that the legislators will accomplish the latter, but not the former. See infra notes $164-89$ and accompanying text.

109. McCabe, supra note 22.

110. STEWART, supra note $20, \S 1.04$. The other justifications include the principle of natural justice, the economic argument, and the social argument. Natural justice supposes that 
is that because creative works form a considerable national asset, rewarding creativity is in the public interest as a contribution to the development of the national culture. ${ }^{11}$ Similarly, the use of neighboring rights was developed to extend protection similar to that of a copyright to those who deserve some degree of protection, but do not qualify for traditional copyright protection. In practice, "the term copyright is often used to include neighboring rights or, in an effort to be precise, the two are awkwardly linked in every statement"-a result of differing understandings of the terms. ${ }^{112}$ To avoid problems in terminology, it is essential to understand Canada's copyright philosophies and origins.

While it seems apparent that a copyright system that had gone largely unaltered for over seventy-five years would be in dire need of update, that same system was arguably effective due to its simplicity. Canadians have always interpreted their copyright laws to include new technology, although the laws themselves were not explicit on this point; to Canadians, a copy was a copy. ${ }^{113}$ Some felt the "Canadian copyright law may be superior to the U.S. law due to the fact it contains less confusing exceptions."114 For better or worse, Canada now has moved away from this relative simplicity with the passage of the new amendments.

Despite the former "keep it simple" approach whereby technological changes were absorbed into the existing law, Canada's philosophy on copyright has never been simplistic. On the one hand, copyright means the right to copy, and, on the most basic level, "all original creative works are protected by copyright in Canada." 115 On the other hand, "Canada has always recognized copyright as a balance of creator and user interests." 116

the "author is the creator of the work which is the expression of his personality. He should be able to decide whether and how his work is to be published and to prevent any injury or mutilation of his intellectual offspring." ld. \$ 1.02. The economic argument suggests that considerable investment is needed for the creation of some works, such as architecture or films. The process of making the work available to the public, such as publication and distribution of books or records, is also expensive, and investments will not be made without a reasonable expectation of turning a profit. Id. $\S 1.03$. Finally, the social argument rests on the idea that the "dissemination of works to large numbers of people forges links between classes, racial groups and age groups and . . . the creators thus render a social service." Id. $\S 1.05$. These four arguments have generally been accepted, but different legal systems usually emphasize one principle over the others. Id.

111. Id. $\$ 1.04$.

112. David Sinacore-Guinn, Collective administration of Copyrights and NEIGHBORING RIGHTS $\$ 3.8$ (1993) (footnote omitted).

113. Briefly from CANCOPY (The Newsletter for CANCOPY Affiliates), Vol. 7, No. 2 (Summer 1997) (visited Jan. 24, 1998) < http://cancopy.com/new.html>.

114. The Copyright Website, What's News, Canada National Newspaper Praises The Copyright Website (visited Nov. 29, 1997) <http://www.benedict.com/new.htm > .

115. About CANCOPY (visited Jan. 24, 1998) < http://cancopy.com>.

116. McCabe, supra note 22. 
This juxtaposition of two typically opposing philosophies on copyright-the traditional Anglo-copyright view, which encourages release of the work to the public, and that of droit d'auteur (author's rights)-has formed a hybrid of competing interests and priorities. ${ }^{17}$ Under Canada's Copyright Act, the person who owns the copyright (usually the creator of the work) has the right to decide when and how the work is copied. ${ }^{118}$ Still, the basic reasons for protecting a work through copyright varies between the two approaches. ${ }^{119}$ Authors' rights countries generally protect the natural rights of the author in his work, whereas countries following the Anglo-copyright tradition are more sensitive to users' interests. ${ }^{120}$

The substantial philosophical differences between the individualistic and idealistic droit d'auteur system and the commercially oriented Anglocopyright system break down in practice. ${ }^{121}$ Both systems grant a high level of protection to creators, although the Anglo-copyright system adapts more easily to new technology. ${ }^{12}$ Both systems were created when the system of privileges, which had been in operation both in England and on the European mainland from the fifteenth to the eighteenth century, was abandoned. ${ }^{123}$ Influenced by the French Revolution, continental European countries followed the French Act of 1783; countries of the common law legal

117. See Fraser, supra note 106, at 801-02. 'Canada's copyright approach exhibits elements of the "Anglo-copyright tradition and that of droit d'auteur more commonly found in the civil law countries of Europe." Id. at 801 (footnote omitted). See also id. at 771 (the difficulty in balancing these views kept the United States from participating in the Berne Convention). However, other countries do attempt to balance these approaches. See STEWART, supra note $20, \S 1.15$ : "Several states like Germany, the Nordic countries, and Japan which ideologically belong to the continental 'droit d'auteur' system are in some respects closer to the copyright system than to the French system." This is particularly true where it grants "performers, producers of phonograms, and broadcasting organizations rights. which they term neighboring rights as they are exclusive rights which are close to and neighboring on copyrights." Id. They do not see the fact that some of these rights may originate in legal entities as opposed to natural persons as a discrepancy. Id. (footnotes omitted).

118. About CANCOPY, supra note 115 .

119. This merger occurred because Canada's Copyright Act was based on the United Kingdom's Copyright Act of 1911, while Quebec subscribes to a civil law system because it is a former French colony. Fraser, supra note 106, at 801.

120. Id. at 771-73. As a further consideration, droit d'auteur stems from the doctrine of natural law and the ideas of the French Revolution, resulting in a personalized copyright approach that joins the work with the personality of the author. STEWART, supra note $20, \S$ 1.13 .

121. STEWART, supra note $20, \S 1.16$.

122. Id. On the other hand, in coping with the difficulties posed by the fact that, increasingly, works are reproduced in employment and by team-work, the droit d'auteur doctrine still has relevance.

123. Id. 
tradition followed the 1709 Statute of Queen Anne. ${ }^{124}$ As it became increasingly apparent that international copyright was a commercial necessity, England and France (the protagonists of each system) became founding members of the Berne Union in 1886. ${ }^{125}$ The Berne Union sought to achieve a set of compromises between the two systems. ${ }^{126}$

With this historical perspective, it is understandable how the need for neighboring rights emerged. The international compromise that eliminated the droit d'auteur doctrine in order to resolve this "philosophical impasse" provided that, while the initial right in the new material is not a droit d'auteur, it is nonetheless an intellectual property right connected with, or neighboring on, the droit d'auteur. ${ }^{127}$ Radio stations in fifty-one countries around the world currently pay a neighboring rights royalty; ${ }^{128}$ as such, neighboring rights are widely applied and relatively common. ${ }^{129}$

Bill C-32's most controversial aspect was that it created neighboring

124. Id.

125. Most nations (most recently the United States), whether of the droit d'auteur or Anglo-copyright tradition, have ratified the convention. The acceptance of neighboring rights into most European and Latin American countries of the droit d'auteur tradition exemplifies the influence of the Anglo-copyright tradition. Id. \$ 1.15. These countries also have ratified neighboring rights conventions such as the Rome Convention and the Phonogram Convention, which are examples of the influence of the copyright concept on droit d'auteur countries. Id.

126. Id.

127. Id. \$7.10. Neighboring rights usually involve rights born from derivative works because neighboring rights presuppose a pre-existing work. For illustration, consider that performers (who are not also the creator) receive protection only if they perform works; music releases (CDS, tapes) are nearly always recordings of a work; and radio broadcasts consist largely of performances of works. Thus, the comparison to be made is with copyrights in other derivative works, which can be of many kinds. The first, historically, was translations of literature into another language, as well as transcriptions of musical works. Later followed derivative works involving a change of medium, such as a book into a movie. It is interesting to note that the stigma that used to attach to derivative works-based on the assumption that the derivative work demanded only technical, not artistic, skill-no longer exists. Id. \$ 7.11.

128. Geddes, supra note 75. "The Rome Convention governs the rights of performers, producers of phonograms and broadcasting organizations. The loosely connected group is said to have 'neighboring rights,' that is, rights similar to, but not subsumed under, national copyright laws." Bonnie Teller, Toward Better Protection of Performers In The United States: A Comparative Look at Performers' Rights in the United States, Under the Rome Convention and in France, 28 Colum. J. TRanSNAT'L L. 775, 800 (1990). Historically, these groups were not considered to have created anything warranting copyright protection on the level of the authors. The Rome Convention sought to overcome this inequity by extending "copyrightlike protection to these performing artists. . . . In 1979, it was estimated that since the adoption of the Rome Convention, fifty-one states had legislated in the field of neighboring rights." Id.

129. See STEWART, supra note $20, \S 1.16$. Overall, the "increased importance of 'neighboring rights' in the 'droit d'auteur' countries . . . [will create a gradual] synthesis of the two philosophies . . . which will greatly strengthen the position of copyright as a legal discipline both nationally and internationally." Id. 
rights. These rights include "a performance right ensuring that performers, musicians, and owners of rights to a master recording (including record companies) will be remunerated when songs are aired on radio. ${ }^{130}$ Prior to the amendments, "only composers and publishers receive[d] a royalty for airplay on Canadian radio." 131 The specific provisions of Bill C-32 that established neighboring rights are contained in Part II of the Act, entitled "Copyright in Performer's Performances, Sound Recordings and Communication Signals." ${ }^{132}$ The original Bill C-32 utilized a five-year phase-in plan for the neighboring rights provisions, but this was accelerated to three years by the Heritage Committee. ${ }^{133}$

Because neighboring rights were developed to provide protection to creators and contributors who were not afforded traditional copyright protection, they signify rights neighboring on the authors' copyright (hence the name), and mainly apply to the rights of performers, the company or investors producing the release, ${ }^{134}$ and broadcasting organizations. Neighboring rights are best exemplified by the rights given to producers of sound recordings, since such producers tend to be business entities rather than individual authors. ${ }^{135}$ The modern concept of copyright stems, directly from the 1709 Statute of Queen Anne in the United Kingdom. At that time,

130. LeBlanc, supra note 103.

131. Id.

132. Act of Apr. 25, 1997, ch. 24, 1996-97 S.C. (Can.) [hereinafter Bul C-32]. Section 15 of the Act addresses "Performers' Rights"; section 18 addresses "Rights of Sound Recording Makers"; section 19 addresses "Provisions Applicable to Both Performers and Sound Recording Makers"; and section 21 addresses "Rights of Broadcasters."

133. Jill Vardy, Copyright bill faces last hurdle as Senate eyes amendments, FiN. POST, Apr. 19, 1997, available in 1997 WL 40922758 . The CAB lobbied unsuccessfully to maintain the five year phase-in term. Id.

134. This type of "producer" should not be confused with the more common association implied by "producer" or "record producer" - that is, the person who literally operates the recording equipment and captures the performer's music on tape. (Of course, producers usually have considerably more input than this explanation suggests.)

135. Fraser, supra note 106, at 769 . "The distinction arose in part because authors" rights countries generally grant protection to natural authors for their creative endeavors. Although corporations may hold certain rights, by definition, they cannot create; only its officers, directors, employees, and contractees can create [on the corporation's behalf]." Id. Compare STEWART, supra note $20, \S 1.15:$ " [A]s the economic argument had always been in the foreground, copyright countries were not shocked by the notion that the first copyright owner in the case of films or phonograms or broadcasting programmes is a company or a corporation." (See supra note 110 for the other three copyright arguments.) The United States only recently began protecting public performances of sound recordings. Fraser, supra note 106 , at 770 . "Many countries, on the other hand, have been providing copyright-like protection to producers and performers under the aegis of neighboring rights, including a public performance right in sound recordings ... on the condition of material reciprocity." Id. 
the law sought to protect the investment of booksellers. ${ }^{136}$ From the beginning then, economic protection was a fundamental goal of copyright, which extended copyright protection to the technological advances of the twentieth century. For example, the works of film producers and broadcasting organizations simply joined "writing" as a means of communicating a work. ${ }^{137}$ "On the other hand, proponents of the pure 'droit d'auteur' concept saw these entities more as users than as creators and would not extend a 'droit d'auteur' to such users." 138 Since it was evident that these entities had created or contributed something warranting protection, neighboring rights developed essentially out of necessity in the droit d'auteur system.

The establishment of performer's rights through section 15 ("Performer's Rights") of the copyright amendments creates new rights in exchange for inevitable costs. ${ }^{139}$ It is paradoxical that of all neighboring rights owners, performers are closest to derivative authors, such as translators of literary works or adaptors of musical scores who receive full author's rights, yet their rights are often the weakest. ${ }^{140}$ Unlike the other

136. STEWART, supra note $20, \S 1.15$. Booksellers were the equivalent of the modern publisher. Id.

137. Id. $\$ 7.08$. Droit d'auteur jurisdictions reacted differently to each new invention presented by technological developments. For example, it was rationalized (through a legal fiction) that a film is no more than thousands of photographs strung together. Id. Everyone who participated in the process became a co-author (authors, cameramen, cutters, actors, directors, composers of accompanying music). It was cumbersome for the film producing company to acquire the rights from the individual co-authors, but when sound recording was invented, the difficulty became unmanageable. Id. To recognize the sound engineer, the record producer (see supra note 134), or the performing artists as co-authors of the recording stretched the fiction beyond the breaking point. "Thus on the international plane for phonograms and broadcasts a new solution had to be found which would be acceptable to 'droit d'auteur' countries." Id.

138. Id. $\$ 7.14$. The emergence of neighboring rights generated considerable concerns among authors. If a user had to "pay two royalties for the same performance, one to the author and one to the neighbouring right owner . . . he would . . . [simply] pay less to the author." Id. Known as the "cake theory" because "[t]here is [supposedly] only one cake and if the neighbouring right owners [took] a slice of it, the slice of the author would be smaller. Practice has proved these fears to be unjustified." Id.

139. Geddes, supra note 75 . "Pay-per-play royalties to be paid to artists and producers" are part of these neighboring rights. Id.

140. STEWART, supra note $20, \S 7.16$. Two reasons for this weakness are postulated by Stewart. The first is historical. "'[S]trolling players' were . . 'vagrants' by the law during the formative period of copyright." Id. Adam Smith, in The Wealth of Nations, used players, musicians, opera-singers, and opera-dancers as "examples of "unproductive labor." Id. Of course the stigma is gone as star performers are idolized in modern society. The second reason is technological. Adam Smith also pointed out that the work of these unproductive laborers "perishes in the instant of its production." ld. Thus, the ephemeral nature of a performance was a valid reason for denying a copyright to performers. But once performances could be fixed and reproduced in large numbers, as well as performed to large 
neighboring rights owners, such as corporations, performers are physical persons, thus making it difficult to justify a difference in treatment of the work of a derivative author (a translator or an arranger) and that of a performer. Nevertheless, performances of the same work by different artists vary greatly in artistic interpretation and execution. ${ }^{141}$ Itzhak Perlman's performance of Paganini's 24 Caprices, for example, obviously will be more valuable than that of an amateur violin student using the work as a techniquebuilder.

The growing pains Canada may experience with neighboring rights are likely to be pronounced. One authority on the Canadian Copyright Act stated that, perhaps for reasons having to do with economic ties with the United States or with constitutional rights, the "Canadian legislature would prescribe as 'copyright' any law that distinguished itself radically from theoretical points of view and judicial concepts." 142 It seems as though "political motives exist to justify, with no bearing upon two centuries' historical judicial practices, ... . [the creation of] laws that concern the exclusivity and particularity of the fruits of creative labour." 143 International copyright law is predicated on principles of national recognition, which allows foreigners to seek protection under Canadian law and Canadians to do the same while abroad. Thus, regarding neighboring rights, Canada now assures the U.S. government that American holders of neighboring rights are protected in Canada. However, under Canadian constitutional law, the legislature's ability to create such neighboring rights is less than certain. Supporters might attempt "to justify the federal legislature's competence [in the copyright field] in light of article 91(23) of the Constitution Act of 1867, which fully enables the federal legislature in authorial rights matters," but such general legislation does not explicitly address neighboring rights. ${ }^{144}$ Due to the newness of neighboring rights in Canada, it remains to be seen whether there will be a sufficient constitutional basis to support the

audiences (thus involving the two basic rights in the copyright bundle, the reproduction right and the performance right), the second reason had also been removed. "The question of what, if any, rights performers should have in law has been debated among jurists and legislators ever since." Id. Even so, there is "no doubt that performers "spend sufficient skill and labour' to merit copyright protection." Id.

141. See discussion infra Part IV. Even granting a neighboring right does not fully compensate performers, particularly musicians, due to "technological unemployment." STEWART, supra note $20, \S 7.25$. Once a performance is recorded it can be repeated without any performer, causing performers to lose employment opportunities. It has been widely recognized that the performance right in recorded performances "benefits the stars far more than ... [average] . . . musicians." Id. Some collecting societies propose to pay those members who have lost such opportunities. Id.

142. Normand Tamaro, The 1997 AnNotated Copyright ACT at xxx (1997).

143. Id.

144. Id. (footnote omitted). 
legislature's provisions.

In addition to neighboring rights, the recent amendments also establish procedural changes, including acceleration of copyright infringement claims as well as increased damages. Prior to the recent amendments, copyright owners could only recover damages to the extent they resulted from the infringement. Statutory damages provisions now guarantee a minimum award once infringement is proven. ${ }^{145}$ The introduction of statutory damages is expected to make enforcement of reproduction rights by individual rights holders more efficient. A copyright holder could demand, in lieu of damages, an award of statutory damages on a sliding scale between $\$ 200$ and $\$ 20,000.146$ This "sliding scale" presents possible difficulties: "while it is widely recognized that it is very difficult to assess damages pertaining to infringements, it would be tempting for judges to use the sliding scale as a tool to evaluate each and every case of copyright violation. ${ }^{147}$

In addition, new procedures in the bill allow claims by copyright owners to be dealt with "without delay and in a summary way."148 From now on, judgments may be obtained without trials using less costly, less time-consuming summary procedures. ${ }^{149}$ Many feel that these provisions are too strong and that they have created "propos[ed] remedies and penalties for copyright infringement that are more severe than virtually every other country in the world . . . [and] make artillery available to kill a fly. 150

Before looking at what these neighboring rights provisions will mean to Canadian radio, it should be noted that external forces also made a strong impact on the shape of the amendments. ${ }^{151}$ Political tension, stemming

145. Id. at xxxiii. It is probable that, in many cases, neighboring rights holders would find a court case too costly to pursue. Cf. STEWART, supra note $20, \S 14.49$. France, in its $1985 \mathrm{Law}$, increased copyright infringement penalties and applied the same penalties to the infringements of neighboring rights. Furthermore, Article 425 of the French Penal Code "punishes any act of infringement ... with imprisonment from three months to two years or a fine of FF 6,000 to 120,000 , or both." Id.

146. TAMARO, supra note 142 , at $x x x i i$.

147. Id.

148. BILI C-32, supra note 132, pt. IV, § 34(4).

149. Briefly from CANCOPY, supra note 113 .

150. Canadian Association of Broadcasters-Television Board, Executive Summary, Submission to the House of Commons Standing Committee on Canadian Heritage Respecting Bill C-32, an Act to Amend the Copyright Act, Sept. 3, 1996 (visited Jan. 23, 1998) <http://www.cab-acr.ca/Statement_C32.htm > [hereinafter CAB Television Board]. See also West's Legal News Staff, Canadian Copyright Bill Could Force Live TV Broadcasts Nationwide, Dec. 5, 1996, available in 1996 WL 692711. The brief news report notes that "since taping a live broadcast would constitute copyright infringement," the bill "would necessitate live simulcasts between time zones, an inconvenience for viewers and broadcasters alike." Id.

151. These tensions lead to a suggestion in Part IV of this note about switching copyright decisions to Canada's Senate to avoid dilution of the copyright amendments due to political 
primarily from the top two government ministers responsible for broadcasting in Canada, surrounded the passage of Bill C-32. ${ }^{152}$ For example, wanting nothing more than to win a round for struggling artists and secure a political victory for herself, the embattled Heritage Minister Sheila Copps tabled seventy last-minute amendments to Bill C-32, after the parliamentary committee had already waded through eighty on its own. However, most of these proposed amendments faced opposition from Industry Minister John Manley, who supported the radio broadcasters. ${ }^{153}$

The extensive-and extensively reported-friction between the federal Heritage and Industry departments has caused uncertainty for Canadian businesses as to which department to look for leadership. ${ }^{154}$ The root of the conflict between Manley and Copps stems from a 1993 federal decision to split responsibilities between the two departments: broadcasting policy was assigned to Heritage, while telecommunications regulation was given to Industry. ${ }^{155}$ The result is that "Industry bureaucrats see themselves as champions of a more open economy and foreign investment," while "Heritage mandarins are custodians of a range of policies designed to foster

pressures. See infra text accompanying notes 186-89.

152. Sheila Copps is the Minister of Heritage; David Manley is the Minister of Industry. These two fought constantly as Bill C-32 made its way through the Canadian channels. Copyright Laws Spur Battle Within Canada, HoLlYwOOD REP., Dec. 11, 1996, available in 1996 WL 11415472. Manley and Copps "most recently clashed over a bid [currently before the Canadian government] by Dutch media giant PolyGram NV" to begin business in Canada. Id. The movement to change the Copyright Act was often subject to political posturing. See MATEJCEK, supra note 18, at 79, 80. In 1984, Conservative Canadian Prime Minister Brian Mulroney came to power after making pre-election promises to revise the antiquated Canadian copyright legislation. At first there was momentum as the new Minister of Communications and Culture, Marcel Masse, stated that the Copyright Act was a top priority. This led to the tabling of From Gutenberg to Telidon in the House of Commons, but no action was taken on the paper after many months of lobbying efforts, meetings, and conferences. Id.

153. E. Kaye Fulton, Pre-Election Jitters: Antics and animosity upset the Liberals' plans, MACLEAN's, Feb. 17, 1997, available in 1997 WL 8471523. See also Knopf, supra note 107 , at 38 (noting that the increasing politicization of copyright law creates serious problems, particularly since copyright laws affect "multi-billion dollar deals and debates concerning trade, the information highway, [and] the entertainment industry"). This reality has brought "the advent of lobbyists, new and larger casts of bureaucrats, and politicians eager to be political." Id. Indeed, an "issue that is still too esoteric for most Canadian law schools has now become a front page headline on a regular basis." Id.

154. John Geddes \& Jill Vardy, Business caught in Ottawa's inter-ministry shootout, FN. POST, Dec. 28, 1996, available in 1996 WL 5749287.

155. Id. In addition, "the two departments share duties where the government's economic-development aims run counter to its cultural-protection goals." Id. While Bill C-32 undoubtedly suffered as a result of this turmoil between Manley and Copps, it is perhaps not entirely their fault. Referring to the legislation that split otherwise closely related responsibilities between departments, the National Director of the Canadian Council of the Arts, Keith Kelly, has stated that "the architecture is so bad it would drive the best of friends apart." Id. 
culture." 156

For legislation that had percolated for almost ten years, the recent copyright amendments should have been more carefully drafted. In light of the seventy-five year process behind the current changes, it is somewhat troubling that Heritage Minister Copps has said that Bill C-32 only "laid the groundwork" for more ambitious legislative efforts, and already "has promised that the next round of amendments will deal with digital technology." 157 Copyright lawyer Leslie Ellen Harris, who drafted the initial version of Bill C-32, admits that the "Canadian government hasn't yet explicitly looked at [copyright] in the context of digital technology." ${ }^{\text {158 }}$ However, the World Intellectual Property Organization (WIPO) has taken action through three new international treaties on exactly this subject. ${ }^{159}$ Without diverting to a separate issue, it is intriguing to consider the passive role Canada played in the WIPO treaties, balanced against the somewhat aggressive stance it is taking with the copyright amendments. "Canada has sent comparatively large delegations, . . . sometimes surpassing in the size the delegations of the USA or EU . . . . However . . . Canada has been an infrequent and low profile participant in terms of statements and interventions in the official recorded proceedings." 160 The WIPO treaties are likely to either directly contravene Canadian law or, at a minimum, set policy in areas Canada has not yet legislated. ${ }^{161}$ This is a vulnerable position

156. Id.

157. Briefty from CANCOPY, supra note 113. See, e.g., Performers Cheer Final Passage of Copyright Bill, supra note 14.

158. Copyright (CANCOPY's Newsletter for Licensees), Vol. 2, No. 1 (Spring 1997) (visited Jan. 24, 1998) <http://cancopy.com/copyright/spg 1997/spring1997.html >.

159. WIPO OMPI, WIPO Press Release No. 106 (Dec. 20, 1996) (visited Nov. 15, 1997) <http://www.wipo.int>. See, e.g., Jill Vardy, Treaty may cause internet headaches: Canada needs ground rules suited to our own realities, FIN. POST, Dec. 5, 1996, available in 1996 WL 5747645; Prudence Adler, WIPO: Summary and Key Accomplishments (visited Nov. 15, 1997) <http://arl.cni.org/newsltr/192/wipo.html >.

160. Knopf, supra note 107, at 35. But cf. Canadian Elected Head of World Intellectual Property Organization (Nov. 14, 1997) (visited Jan. 23, 1998) <http://www.dfaitmaeci.gc.ca/english/news/press_ $\sim 1 / 97$ press/97_188E.HTM $>$. For an intriguing twist on these WIPO events, consider the recent announcement that Sheila Batchelor, Canada's Commissioner of Patents, Registrar of Trademarks, and CEO of the Canadian Intellectual Property Office, has been named Chair of WIPO's General Assembly. Id.

161. Jill Vardy, Copyright bill amendments introduced to committee, FIN. POST, Dec. 4, 1996, available in 1996 WL 5747569. For example, the "treaties would . . . supersede the report of the Information Highway Advisory Council (IHAC), an industry-government group mandated to help Ottawa set new policy." Jill Vardy, Copyright law imperiled by new treaties, FIN. POST, Nov. 30, 1996, available in 1996 WL 5747280. "[T] he IHAC report said more consultation is needed before Ottawa decides how browsing on the Internet should be treated under copyright law." Id. The issue is whether "calling something up on [a computer] screen constitute[s] a reproduction that is subject to copyright law and compensation ...." Id. The WIPO treaties could put Canada in a situation where the ability to "devise laws that 
in which Canada has put itself-a position likely not contemplated during the deliberate and intentional (if misdirected) maneuvering that led to the passage of the Copyright Act amendments.

\section{THE DEVIL's IN THE DETAIS: WHY THE COPYRIGHT AMENDMENTS Will BaCKFIRE ON CANADIAN CUltuRE}

The arguments concerning the establishment of neighboring rights in the Canadian Copyright Act center around the competing priorities of radio broadcasters, record companies, and the creators and performers. The traditional relationship between the record and radio industries allowed radio stations to benefit from the use of music to attract listeners; in turn, this broadcast exposure helped performers and record companies sell records. ${ }^{162}$ The economic advantage that radio provides for record companies and the artists was the main argument behind the lobbying by the Canadian Association of Broadcasters $(\mathrm{CAB})$ for a full neighboring rights exemption in the amendments. ${ }^{163}$

The CAB Radio Board focused on several areas of Bill C-32 in its proposals to amend the bill. Its principal argument was that neighboring rights would hurt local radio programming and local artists by placing Canadian radio stations at a competitive disadvantage with its American

suit [Canada's] needs is circumscribed." Id. The WIPO's database treaty also was of concern to Canada, which felt the premature treaty should be rejected (though the United States aggressively pushed for it). Id. Furthermore, Article 7 may make it impossible for Canada to allow "fair dealing," which permits free copying of small portions of a copyrighted work for private study or research purposes. Id. "Article 7 would extend copyright beyond anything in the current Copyright Act or in Bill C-32. It addresses issues around which there is no consensus in Canada." Id. See also Fraser, supra note 106, at 781 (observing that the WIPO treaties give authors and neighboring rights holders the exclusive right to authorize the distribution of their works).

162. Executive Summary, Submission to the House of Commons Standing Committee on Canadian Heritage Respecting Bill C-32, an Act to Amend the Copyright Act, Sept. 3, 1996 (visited Jan. 24, 1998) <http://www.cab-acr.ca/Sub_rc32.htm> [hereinafter CAB Executive Summary]. "The Canadian Association of Broadcasters represents more than 375 of Canada's private radio stations." Id. The non-profit organization ensures "that the laws and regulations governing the broadcast industry are suited to the industry's long-term health and service to Canadians." Id.

163. Id. As an alternative to a full neighboring rights exemption, $\mathrm{CAB}$ proposed certain limitations: (1) "the proposed base exemption should increase with the Consumer Price Index"; (2) "the wording should be strengthened in the Bill where the Copyright Board is [instructed on] . . . (a) the value of airplay, (b) payment based on eligible recordings, and (c) payment based on volume of recordings used in setting a tariff"; and (3) eligibility for neighboring rights payments should be more strictly defined to reduce payments to the United States (which will not provide reciprocal payments to Canada). Id. None of these proposals was implemented. 
counterparts. ${ }^{164}$ However, these concerns involved more than the radio industry trying to protect its profit margins. After fifteen years of financial losses or only marginal profits, the radio industry had already begun to make drastic expenditure cuts, and modest estimations predict the recent copyright amendments will cost these stations up to $\$ 13$ million annually in new copyright fees. ${ }^{165}$ Prior to the amendments, radio stations paid about $\$ 22$ million a year to the authors and composers of the songs they played. ${ }^{166}$ The impact of these additional, significant expenses will quickly translate into the loss of local station jobs, because the radio stations will have to absorb these new costs that cannot be passed onto advertisers. ${ }^{167}$ This in turn will swiftly damage the local programming content of private radio stations. Local programming has been a primary reason "why Canadians . . . listen to local radio for more than 22 hours a week, instead of turning to American stations." 168

The wide-spread injunctive powers and statutory fines that were created through Bill C- $32^{169}$ will also weigh heavily on radio stations because in many cases obtaining appropriate clearances for music will be prohibitively expensive. "These new expenses will fall as heavily on small stations as large ones ${ }^{170}$ within Canada:

[m]ost radio stations in Canada belong to companies which own two or more stations. The bigger, more profitable stations have often carried their less profitable counterparts during these lean years. The bottom line is that if larger stations are saddled with

164. CAB Opening Statement, supra note 58. Interestingly, CAB does not categorically oppose neighboring rights, such as those that would counteract the effects of new technology on music sales; but radio fully compensates the music industry acting as the "marketing arm of the recording industry" (by providing free airplay, talent development, and artist and concert promotions). McCabe, supra note 22.

165. CAB Executive Summary, supra note 162.

166. CAB Opening Statement, supra note 58. Because authors and composers (despite being the original creators) receive only forty cents per $C D$ from record sales, this amount has always been considered fair. Id. See app. A.

167. CAB Executive Summary, supra note 162.

168. Id.

169. For example, see BILL C-32, supra note 132 , pt. IV, § 38.1(1):

[A] copyright owner may elect, at any time before final judgment is rendered, to recover, instead of damages and profits referred to in subsection 35(1), an award of statutory damages for all infringements involved in the proceedings, with respect to any one work or other subject-matter, for which any one infringer is liable individually, or for which any two or more infringers are liable jointly and severally, in a sum of not less than $\$ 500$ or more than $\$ 20,000$ as the court considers just.

170. CAB Executive Summary, supra note 162. 
Neighboring Rights, they will be less able to cross-subsidize smaller stations, and the smaller stations will suffer. ${ }^{171}$

Once the trimming of costs begins, cuts will likely start with local radio services-the very stations most capable of tailoring the programming to local listeners. Beyond these potential problems, which are strictly the concerns of Canadian stations, is the stark reality that U.S. stations will not be impacted at all by neighboring rights. ${ }^{172}$ Basic business principles, if not common sense, dictate that the Canadian border stations cannot consistently maintain higher cost structures than those in the United States and still remain competitive.

Promoting new Canadian artists also poses substantial financial risks for radio stations. One of the most successful Canadian artists of late is Alanis Morissette, whose history with Canadian radio exemplifies these risks. One station took an interest in her before any other station would give her a chance. Over an eight-year span, the station spent $\$ 42,000$ on her: "We shamelessly featured her, invited her to co-host various shows, and hired her to play at community events. ${ }^{n 173}$ The reality is that competition is fierce and most artists rarely achieve Morissette's level of success. One radio industry spokesperson reports that "[e]very day, someone shows up at our door looking for a break ... . hoping they will be the next Alanis or Neil Young." ${ }^{174}$ Under the new copyright amendments, when a local performer asks to have his song played on air, it may no longer be possible because confirming the rights holders and getting permission from each creator and music publisher will be cost-prohibitive and time consuming. ${ }^{175}$

The financial struggles of private Canadian radio stations should not be interpreted as a sign of failure. ${ }^{176}$ In fact, Canadian broadcasters have competed head-on in every border town with the American broadcasting system. But even before the amendments, Canadian radio paid fifteen

171. CAB Opening Statement, supra note 58.

172. Id. Even without neighboring rights expenses factored in, Canadian radio stations spend $15 \%$ more than U.S. stations on copyright expenditures. Id.

173. Id. The $\$ 42,000$ was a prudent investment in Alanis' case. See Lynn Brenner, What People Earn, PARADE MAG., June 22, 1997, at 5. Morissette's 1996 earnings topped $\$ 22$ million, primarily from record sales of over $9,000,000$ to date. She was 23 years old on the Parade report's publication date. Id.

174. CAB Opening Statement, supra note 58.

175. Id. Even if the performer claims the composition as his own, the risk of infringing on a copyright or neighboring right will be too great in light of the statutory and injunctive provisions contained in the new amendments. Id.

176. See supra note 76 and text accompanying notes $76-78$ for evidence of radio's consistent popularity. 
percent more for copyright than did U.S. stations, which has made the prospect of paying significantly higher amounts due to neighboring rights a critical concern for Canadian border stations. ${ }^{17}$

The fears and concerns engendered by the establishment of neighboring rights are compounded by various administrative uncertainties. The method for collecting and distributing the neighboring rights fees has yet to be established, and the Canadian copyright board has not yet determined the percentages at which neighboring rights holders will receive remuneration. ${ }^{178}$ The establishment of neighboring rights will also require some sort of collection agency. Some music industry sources support a fifty-fifty split of revenue between the record company and musicians. ${ }^{179}$

Administration of the neighboring rights revenue will be complicated, and administrative costs will likely erase any profits for some time to come. First of all, half of the collected revenue will leave Canada because fifty percent of eligible recording-industry repertoire is foreign. ${ }^{180}$ Furthermore, the start-up costs of incorporation, tariff submissions, database management, and enforcement, along with the costs of preparing policies and creating management structure, are substantial. Estimates suggest that, from the time of full enforcement of the neighboring rights, it will take almost five years to break even and will require close to $\$ 10$ million before there is a plus figure. ${ }^{181}$ Predictably, when the discussion turns to who should bear these costs, there are few volunteers. ${ }^{182}$

While SOCAN (Society of Composers, Authors, and Music Publishers of Canada - the Performing Rights Organization of Canada Ltd.) supports the principle of neighboring rights, it has resisted launching a neighboring rights agency because $\mathrm{CAB}$, in its pursuit of full exemption from neighboring rights for all private radio stations, has sought in the alternative a reduction in royalties payable to SOCAN. SOCAN naturally is opposed to any dilution of its radio tariffs to help pay for neighboring rights. While there is widespread endorsement in the music industry for a single agency to oversee the neighboring rights tariffs and revenue, and even general agreement for the agency to operate on the basis of a fifty-fifty split, several industry

177. CAB Opening Statement, supra note 58.

178. LeBlanc, supra note 103. See STEWART, supra note 20, §7.50. In some countries, the "whole protected repertoire is licensed in bulk for an annual sum ... [that] is divided among right owners according to the amount of time their records have been played"; others provide payment "according to a minute rate for protected music." Id. Radio stations would have to keep and furnish logs showing all programs broadcast that would be analyzed to ascertain which releases were protected. Id.

179. LeBlanc, supra note 103.

180. Id.

181. Id.

182. Naturally, it would be harder for individual performers to collect the payments than for a corporation to do so. Id. 
observers doubt that recording artists would be able to hold on to the profit. ${ }^{183}$ Record companies, or "labels," feel entitled to keep revenue generated by the master recordings they have paid for, and thus take the position that, if anything, fifty percent should go towards the recoupment of the label's expenditures for the artist. ${ }^{184}$ If labels do not receive the neighboring rights revenue, they will offer less favorable terms in their recording contracts, because the labels are usually in a superior bargaining position. Labels often argue that since they (the record companies) do not receive income from merchandising, publishing, or touring, artists should not "complain about (the low royalty rate), because we're giving you a start and we're spending all this money." 185 Record companies may also stop giving big advances and start cutting back on tour support. A subsidiary problem is that smaller independent labels, which are traditionally more willing to support unknown artists, will feel pressured to give up their share of neighboring rights revenue in order to compete with larger record companies. As demonstrated by these scenarios, the neighboring rights provisions have the potential to send shock waves through the music industry and produce harmful repercussions that may not have even been considered by the drafters of Bill C-32.

One intriguing, if unlikely, proposal would alleviate some of these administrative hurdles while having the added benefit of reducing the political influences that complicated Bill C-32. ${ }^{186}$ The proposal calls for establishing "a Senate Committee with ongoing responsibility to deal with intellectual property. ${ }^{187}$ The Senate could then initiate copyright legislation. The rationale is that Senators often have experience in broadcasting, cable, or media and the arts, and "[i]t is said that they have time on their hands." 188 The Canadian Senate often gives a more considered, less partisan review of intellectual property legislation than does the House of Commons. The Senators are more insulated from "interference by Ministers, their staffs, and bureaucrats than Members of Parliament." 189

While most of CAB's lobbying efforts have been based on credible statistics and arguments, there appears to be some doubt surrounding its argument that performers and record companies profit amply from the sales of recordings and concert tickets, earning " $\$ 2$ to $\$ 3$ from the sale of each

183. Id.

184. Id. The up-front costs that labels pay to launch a new act are considerable. See app. A.

185. LeBlanc, supra note 103.

186. See supra notes $151-56$ and accompanying text.

187. Knopf, supra note 107 , at 39 .

188. Id.

189. Id. 
successful CD. ${ }^{190}$ In actuality, the figure is much lower for performers, and potentially much higher for record companies. In the past, the music industry has relied on the mutually beneficial relationship between radio and record companies. Since radio exposure generates sales for the artists and record companies, these sales were traditionally considered radio's full compensation to performers. ${ }^{191}$ However, this balanced relationship has been thrown off by technological developments that impinge on legitimate record sales. Performers' revenues are increasingly threatened by unscrupulous people who make perfect copies of a commercially released CD using digital recording equipment, and then post it on the internet for anyone else to make a digital quality copy-without paying. While this is a formidable problem that requires some sort of remedy, "radio does not contribute to this problem and should not have to pay for it through Neighbouring Rights." 192

If the money will indeed go to any artists, only those who are already superstars will receive any measurable amounts. More likely, the money will go to the record labels that will have required newly acquired artists to assign their copyrights to them. ${ }^{193}$ High-income Canadian recording artists like Bryan Adams and Tom Cochrane undoubtedly will profit from the royalty. But less popular artists are less hopeful; for example, the rising country artist "Sky" recently returned to Canada after spending ten years in the United States. Sky would welcome any monetary gain from the royalty because it would boost performers "like herself who are just beginning to get radio air play." 194 The problem is that thousands of musicians would do nearly anything for a recording contract; this creates a buyer's market, and the record companies can easily exploit this situation to their advantage. ${ }^{195}$

Clearly there are considerable misconceptions as to how much successful performers earn. Many assume that vast riches await all performers lucky enough to sign a record deal. In reality, record companies and their lawyers may take advantage of musicians who do not understand their legal rights, the meaning of obscure clauses in lengthy contracts, or the

190. CAB Opening Statement, supra note 58.

191. Id.

192. Id.

193. Paul W. Weber, Serious Problems with Copyright Bill, Fin. Post, May 3, 1997, available in 1997 WL 4093910.

194. Geddes, supra note 75.

195. See Donald S. Passman, All You NeEd to KnOw About the Music Business (1994). Throughout his book, Passman wams of the uses and abuses of the various players within the industry. "There have been a lot of big names associated with disasters over the years." Id. at 40 . See generally id. at ch. 3 (Personal Managers), ch. 4 (Business Managers), and ch. 5 (Attorneys) for advice in avoiding industry abuses. See also 1996 SONGWRITER'S MARKET: WHERE \& HOW TO MARKET YOUR SONGS (Cindy Laufenberg ed., Writer's Digest Books 1995). The "music industry has its share of dishonest, greedy people who try to unfairly exploit the talents and aspirations of others." Id. at 13. 
ramifications of giving up vast amounts of their own publishing rights to the record label. ${ }^{196}$ A financial breakdown of an artist who not only has beaten the odds and acquired a record deal, but who also has had the extraordinary luck of having his or her first release achieve gold status (selling 500,000 units), illuminates the financial realities of the music business. ${ }^{197}$

Because the establishment of neighboring rights will probably not help new Canadian artists, the copyright amendments will do little to promote Canadian culture. Since the new protections will only benefit artists already receiving royalties, and may also face constitutional challenges, a recent editorial in The Financial Post suggested that it may be better to boost cultural grants directly to artists. Nevertheless, a response in the following issue panned the idea as "the type of thinking that has kept Canada's copyright reform behind most Third World countries for 74 years." 198

Artists may benefit more from the tried-and-true Canadian content laws, which require radio stations to devote a certain amount of air time to Canadian artists. However, the continuing need for these regulations is increasingly under fire. ${ }^{199}$ Established superstars like Alanis Morissette and Celine Dion are examples of how competitive the Canadian music industry has become. Even so, without Canadian content regulations, many radio stations might stop playing Canadian music. ${ }^{200}$ Michael McCabe, president

196. See PASSMAN, supra note 195. Many artists "have never learned such basics as how record royalties are computed, what a copyright is, [and] how music publishing works." Id. at 23. Discussing the need for artists to be represented by a manager or lawyer, Passman explains that major record companies have a policy of not accepting submissions unless they come from a manager or attorney in the business. Id. at 34 . "The reason for this practice is that record companies can get 300 to 400 tapes per week, and restricting who can send in tapes is one way they regulate the floodgates." Id. (emphasis in original).

197. See app. A.

198. Brian Robertson, Copyright Bill a Step Forward. FIN. PosT, May 3, 1997. But see Etan Vlessing, Trading Shots: Canada's Culture Czars Wrap Themselves in the Flag. But Who Are They Protecting?, HOLLYWOOD REP., Nov. 25-Dec. 1, 1997, at 16 (discussing the practice of governmentally issued tax credits to entertainment companies that meet quotas). However, "the tax credit and subsidy schemes . . . actually favor large, vertically integrated producers who create programming for the world market-typically based on ideas from U.S. shows, books or characters." Id. at 17. The dilemma is, as articulated by Patrice Theroux, executive vice president of Alliance Communications Inc., that the "tiny size of the Canadian market means international sales are essential to the bottom line." Id.

199. Shawn Ohler, CanCon Debate Rages On and On; Proponents Argue Law Necessary to Ensure Homegrown Artists Heard, EDMONTON J., Mar. 7, 1997. These laws are also extremely controversial and recently became a hot topic after federal Trade Minister Art Eggleton proposed changes to the regulation. ld.

200. Id. See NASH, supra note 23 , at 259 . There may be other dangers in reverting to "old ways" in light of an unofficial CBC philosophy that became apparent in the early 1960 s. Various performers complained of there being no "star system in the CBC to develop TV headliners." Id. Alex Barris, a well-known variety show host, said: "The CBC's determination to deflate show business egos is clear. . . The CBC has always been uneasy 
of the Canadian Association of Broadcasters, has suggested that "the government should reduce the 30[\%] requirement to reflect Canadian consumers' music preferences, [based on the fact] that 13[\%] of record sales in Canadian retail are by Canadian artists. "201 Based on the idea that the law has made radio stations less attuned (so to speak) to listener preferences, this position reflects the sentiment that content laws are no longer necessary to protect national culture. ${ }^{202}$

Regardless of the reasons behind the results, Canada has produced a long list of music and musicians who have achieved great success in the United States. Adding to the irony and complexity of this situation, then, is the possibility that Canada's secret weapon in combatting the U.S. cultural invasion may well be the Canadian musicians themselves. Americans have not been oblivious to this possibility, and have gone so far as to state that Canadian cultural protection is just economic favoritism in disguise. ${ }^{203}$ One U.S. lobbyist said that Canadian singers are welcome in the United States, but U.S. singers "are treated like skunks up north."

The content laws have produced ridiculous situations in which some artists do not qualify as Canadian artists under the laws due to mere technicalities. Bryan Adams, a massively popular Canadian pop star, has faced challenges from the CRTC as to whether his music satisfies the

about proclaiming anyone as a 'star.' Id. Another Canadian icon known simply as Juliette agrees: "The corporation . . . [never] wanted anyone to have the kind of power a real star has because then they couldn't control them." Id. Nash suggests that "at the CBC, it was the producers, not the performers, who were treated like stars." Id.

201. Ohler, supra note 199.

202. Id. But see Christopher John Farley, Gallapalooza! Lilith Fair-A Traveling Festival Featuring Female Folk-Pop Stars-Is Rocking the Music World, TME, July 21, 1997. at 60-64. There are subtle discrepancies between American and Canadian artists. For example, one of Canada's fastest rising artists as of late 1997 was Sarah McLachlan, organizer of the best-selling tour of the 1997 summer concert season, Lilith Fair. Nevertheless, the Time cover story, reporting on the success of a revolutionary, all-female tour, featured American artist Jewel on the cover. Jewel played less than one-third of the Lilith Fair dates; McLachlan, as the organizer, was the only artist to play every date of the tour. See also ReMail, REQUEST MAG., Oct. 1997, at 4 (responding to a previous McLachlan feature story that attributed her double platinum success to radio support, one reader stated that "the thing that turned me on to McLachlan's music was not . . . radio, but rather a Canadian TV show called Due South. It is shot in Toronto and distributed around the world. Several of McLachlan's songs have appeared on Due South.").

203. There is substantial evidence that the U.S. recognizes the importance of Canadian radio. See MATEJCEK, supra note 18, at 15 . For example, as far back as 1969 , when BMI Canada launched the BMI Canada Awards Dinners, the event was "attended by some of the most prominent personalities of the ... US music industry and public life." Senator and Mrs. Albert Gore, Congressman Richard Fulton, Governor Frank Clement of Tennessee, President of Capitol Records Stan Gortikov, and President of BMI Edward Cramer were among the attendees. Id.

204. Lehmann, supra note 12, at 207. 
content-regulation criteria. ${ }^{205}$ The criteria require that, in order to be considered a Canadian performer, at least four of the song writers, producers, and sound recorders involved in the making of the song must be Canadian. ${ }^{206}$ Adams had co-written one song with a friend from England, and consequently the song could not be considered the product of a Canadian writer. ${ }^{207}$ Still, although the content laws did produce an unfortunate result on this one occasion, the same laws arguably were responsible for elevating his career to a point where he could even experience this phenomenon. ${ }^{208}$ The Minister of Heritage has stated that the Canadian music industry has "blossomed and developed a critical mass of artists, because of Canadian content rules." 209

In its quest for cultural independence, perhaps Canada should leave the training-wheel stage of content laws. "Some worry . . . that protectionism risks making Canada look backward and reactionary in the global economy. "210 Canadian culture appears strong enough to now stand on its own merits. There is a degree of appealing logic in the argument that if it is worthy, it will be competitive. Insisting on content regulations "for reasons of cultural nationalism is therefore ironic and possibly selfdefeating." 211 The cost of direct regulation of private broadcasting will invariably exceed the cultural benefits, and Canada's "obsession with quantity must yield to a commitment to less, but better and different, Canadian programming." 212 If cultural regulation of broadcasting is to become more effective, the "first step will be for legislators, regulators, and the public to abandon the National Broadcasting Dream, to acknowledge the external realities of American stations and commercial dominance, and to devise new policies in light of these realities. "213 As such, Canada should abandon the preoccupation with quantity when it comes to promoting Canadian artists. It has even been suggested that little of cultural

205. Macdonald, supra note 82, at 264-65.

206. Id.

207. Id.

208. Id. at 265 . " $[\mathrm{H}]$ is success as a Canadian . . . singer is not coincidental, because the Canadians were very seldom on the popular music scene prior to 1976 . But since the rules went into effect, they have had a very prominent role." Id.

209. CAB Opening Statement, supra note 58.

210. Vlessing, supra note 198 , at 16 . It is interesting to consider the fact that, as artists of the cultural industry began equating Canadian content with trash, the CBC picked up on this view. When advertising the sitcom Mosquito Lake in 1989, the CBC used a slogan saying, "[w]e're on the CBC . . . but watch us anyway!" Lehmann, supra note 12, at 200-01.

211. Manning, supra note 1, at 13.

212. Bruce Feldthusen, Awakening from the National Broadcasting Dream: Rethinking Television Regulation for National Cultural Goals, in BEAVER, supra note 1, at 43. Feldthusen also asserts that "[c]ommercial television is the source of our cultural problems, not a vehicle for solving them." Id. at 64 .

213. Id. at 65 . 
significance will ever be achieved by private broadcasters; however they are regulated, because:

the quotas . . . are simply not powerful enough to overcome the tremendous commercial advantages of American programming. So much is at stake that the commercial broadcasters will always lobby to reduce the impact of the regulations. So great are the net revenue differentials between Canadian and American programs that the commercial broadcasters will always prefer to schedule American programs during peak periods. ${ }^{214}$

A recent Maclean's article shows the poignancy of this commercial threat. The editor commented on the uncelebrated crossing of the border by Howard Stern, the immensely popular trash-talk DJ. ${ }^{215}$ Such indignities support the notion that the tide is turning in Canada and radio stations are approaching the financial breaking point. Traditionally, Canadian broadcasters have seemed to prefer the high-ground in programming, even if such programming decisions would not be the most profitable. For example, in all of the reports and evaluations of the CBC over the years, one clear message can be ascertained: "what matters most is not the plumbing of organizational structure, flow charts, or 'repositioning' strategies, but the content of programming." 216 Those days may be waning, as the advent of Howard Stern on Canadian airwaves seems to indicate.

Private efforts may be preferable to legislation, such as copyright amendments and content laws, designed to foster culture. Sixty-six percent of Canadians do not have confidence in the ability of the government to protect Canadian culture and identity. ${ }^{217}$ One fear is that government involvement can quickly result in a subtle form of censorship. Without any copyright protection, creators can be forced to resort to forms of patronage, which, in modern times, comes largely from the state. ${ }^{218}$ If creators were

214. Id. at 62.

215. Robert Lewis, From the Editor: Tuning in to Trash Radio, MACLEAN's, Oct.13, 1997, at 2. Stern is quoted in the article as saying "[m]ost stations we go on are usually in the toilet. No successful station in its right mind would put us on." Id. Since September 2, 1997, his syndicated show has aired on two Canadian stations that are struggling to improve their ratings, thereby putting their federal licenses at risk because of Stern's raunchy content. While early reports indicate that Stem has improved ratings, a rival broadcaster said that his competitor's decision to carry Stern's show put about $\$ 800,000$ in his pocket due to ad cancellations on the station airing Stern. Lewis concludes that "[p]rotecting a distinctive culture along the $49^{\text {th }}$ parallel will become a larger challenge, especially if civilized dialogue is overtaken by trash talk." Id.

216. See NASH, supra note 23 , at 11 .

217. Lehmann, supra note 12 , at 198.

218. STEWART, supra note $20, \S 1.19$. "The absence of such censorship is an essential 
dependent on the state, a subtle form of censorship could emerge. Still, although an "up-to-date and virile copyright law in a free society will greatly assist its preservation . . . a bad copyright law may help to destroy it."219 Even the United States has experienced the effect of well-intended legislation harming what it is designed to promote. By the time the Constitution was drafted, twelve of the thirteen colonies had passed copyright legislation, following the Statute of Anne, but with "one major deviation from English law: foreign authors were not protected. "220 While concentrating protection exclusively on American authors may have seemed like a good idea at first blush, "the new law sanctioned the unrestrained reprinting of popular English writers, to the disastrous competitive disadvantage of the very indigenous American literature it was pledged to encourage. "221

Yet another financial dilemma that the copyright amendments present involves the traditional use of governmental subsidies and tax measures that the CRTC has used to help broadcasters combat the onslaught of American culture. For example, "until 1987, any investment in a Canadian-produced film was 100 percent tax-deductible." 222 Similarly, "[t]otal Canadian direct and indirect federal arts subsidies in 1989-1990 were estimated to be Canadian $\$ 2.93$ billion. "223 In the wake of the recent copyright amendments, Canadian subsidies likely will decrease because of the perception that new streams of income will be generated. "[S]ubsidies to Canadian artists will now disappear even faster than before, with the new law serving as a convenient neo-conservative excuse. 224

For a country of Canada's international stature, "[t]he proper forum

ingredient of a free society." Id.

219. Id.

220. Id. § 2.18 .

221. Id. "It took a century of agitation to remedy this fatal error." Id. In the meantime, Edgar Allan Poe, James Fenimore Cooper, and Herman Melville "were pirated in England and the reprints sold at cheap prices so that the legitimate product could not compete," resulting in the authors losing their rightful monies. Id. See also THE OXFORD COMPANION TO AMERICAN LITERATURE (James D. Hart ed., 5th ed. 1983). Ironically, Melville traveled to England in 1849 to legitimize foreign publication arrangements. Id. at 485 . One may wonder about the economic detriment such pirating caused Melville. In typical artistic fashion, Melville died broke in "complete obscurity." Id. at 486.

222. Carlson, supra note 6 , at 588. Bill C-58, a tax measure, would deny "advertising cost deductions for Canadian businesses that attempt to reach their domestic market by advertising in non-Canadian media." Id.

223. Id.

224. Knopf, supra note 16 . In contrast to the inefficiency and awkwardness of a government attempting to legislate for cultural promotion, private successes frequently promote Canadian culture. A recent example came by way of CAB's creation of the annual "Canadian Radio Music Awards." CAB Press Release, supra note 57. This "gala event" is designed to "promote the careers of rising stars, boost the sales of Canadian music and help bring more great talent onto the international scene." Id. 
in which to seek co-operation . . . must be multinational. "22s Accordingly, a multinational agreement on information trade, which would be binding on all parties, seems like a prudent proposal: "Information, education, and entertainment are too closely linked in domestic government policies and in the market not to be linked in international trade policy."226 Particularly in a world moving ever closer to a global economy, cultural development will expand to an international, rather than merely national, priority. To that end, Canada and its allies, most likely led by the United States, "should be able to negotiate better conditions for all of us, to institute something approaching fairness in cultural relations. We need a GAIET, a General Agreement on Information and Entertainment Trade, to walk through freely and proudly. $" 227$

It is evident, as seen in the GAIET proposal and the recent WIPO treaties, that Canada must look beyond its own borders in seeking to promote its culture. Furthermore, Canada must not underestimate the impact of its efforts, as viewed by other countries, in defining Canadian culture. Canadian commentators regularly disagree about Canada's role in the international community. ${ }^{228}$ The shadow cast by the United States "may inhibit Canadians from acting on the world stage in an un-Canadian strident manner." 229 Given the "tremendous resources and competence of its government officials," Canada could certainly take a more prominent role in world affairs; nevertheless, this aspiration has been stalled by ten provinces pulling "in different directions and cling[ing] to protectionist tendencies inappropriate for a middle power. ${ }^{230}$ Canadian political scientist Stephen Clarkson stated almost thirty years ago that Canada "cannot afford not to exploit the nation-building potential of our foreign policies since the way others perceive us-dynamic and bicultural, or ineffectual and divided-can strengthen, or undermine, our own national identity. "231 As the new millennium approaches and the nations of the world increasingly move toward a global economy, Clarkson's words resound with a sustained relevance.

\section{CONCLUSION}

The financial impact that neighboring rights will have on Canada's private radio industry remains to be seen, and the picture will likely not

225. Ostry, supra note 3, at 41 .

226. Id.

227. Id.

228. See supra text accompanying note 160 .

229. Fox, supra note 9, at 32.

230. Id.

231. Id. (citation omitted). 
come into focus for several years. Private radio has struggled financially for some time, and the neighboring rights provisions, established through the recent Bill C-32, will increase the economic burdens. At the same time, there can be no question about the integral role private radio stations play in promoting Canadian culture.

Stepping back from the complex inter-relatedness of copyright laws, political posturing, cultural fragility, and the limitations on a government attempting to strengthen its identity (all of which contributed to the shape and scope of Bill C-32), reveals a more fundamental consideration involving the process of creativity itself: the creative process is one of "change, of development, of evolution, in the organization of subjective life. "232 The "inventive minds through whose activity that evolution has been initiated . . . have usually been the only ones much concerned with it. ${ }^{233}$ More often than not, society has hindered rather than furthered these efforts:

There is little comfort in reflecting that vital change has gone on despite all opposition or indifference, that the work of Galileo was done and put to use in spite of obstruction and that Bartok composed a great deal of music while enduring the neglect that left him in sickening poverty. There is no way of estimating how much the development of humanity has been lamed by such delay and waste. ${ }^{234}$

By implication, then, the general good of humanity would benefit from an "effort to foster the invention of life," but such an effort can only be effective and meaningful if it is guided "by insight into the nature of the creative process." ${ }^{235}$ By "[u]nderstanding the activities of those who supply the needs of life, both their own and others', by defining some fresh organization of subjective processes, we may help them get their work done."236

These considerations raise the unanswerable question as to the extent to which Canada can expect its efforts to promote its culture. Such a goal may be inevitably beyond the scope of any government's regulation. Perhaps Canada should be reassured that truly creative people will continue

232. Brewster Ghiselin, Introduction to The Creative Process-A SYMposium 12 (Brewster Ghiselin ed., 1952). This collection includes essays on the process of creating by such notable visionaries as Albert Einstein, Vincent Van Gogh, Friedrich Nietzsche, Carl Gustav Jung, Mary Wigman, A.E. Housman, W.B. Yeats, Henry Moore, and D.H. Lawrence, among others.

233. Id.

234. Id.

235. Id.

236. Id. 
to create, no matter what the national flag or geographic region, no matter what degree of governmental interference. Canada has a good chance of enjoying a unique identity, then, almost in spite of itself. C.G. Jung has stated "[t]he work in process becomes the poet's fate and determines his psychic development. It is not Goethe who creates Faust, but Faust which creates Goethe. "237 By extension, no matter what the Canadian government does to foster and promote its national identity through its culture, it is not Canada that will create its culture. It is the culture that will define Canada.

Jonathan L. Faber*

237. Id. at 13.

* J.D. Candidate 1999, Indiana University School of Law-Indianapolis; B.A., 1994, Wittenberg University, Springfield, Ohio. The author has dual-citizenship between Canada and the United States. Several of the author's classical guitar compositions were published by Time Warner AudioBooks as part of the production Puerto Vallarta Squeeze (by Robert James Waller); in addition, the author independently publishes original works of music. The author thanks Dr. J. Arthur Faber, Professor of English, Wittenberg University, and Professor Trudy Faber, Music Department Chairperson and Professor of Music, Wittenberg University, for their critical contributions in the drafting of this note. 


\section{APPENDIX A ${ }^{238}$}

*Figures in U.S. dollars.

If the cost of a $C D$ is rounded up to $\$ 16$ and multiplied by 500,000 , the figure comes to $\$ 8$ million. From the $\$ 16$ list price a $25 \%$ packaging charge is deducted. Thus, the cost of the record as determined by the record company is down to $\$ 12$. This is multiplied by $8 \%$, the artist's net royalty rate per record sold (assuming a royalty rate of $11 \%$ after the industry standard deduction for the producer's take, which is $3 \%$ ). The base royalty rate for each record sold is $\$ 0.96$. Rounded up, $\$ 1$ multiplied by the number of units sold equals $\$ 500,000$, the base amount due to the artist. Now it gets interesting:

$\$ 500,000$ records sold

(75.000) $15 \%$ deducted for freebies, promos, review copies for radio/magazines

425,000 Total new royalty base due to the artists

(148.750) $35 \%$ of royalty held in reserve by record companies for returns

276,250 new royalty base paid band after freebies and returns are deducted

(27.625) $10 \%$ deducted by record company for breakage or returns

248,625 Total paid to band by record company; band can start using this money

(150.000) recording expenses: studio/engineer's time, equipment rental, per diems

98,625 Band's gross earnings after expenses

(19.725) manager's $20 \%$ of the band's earnings

78,900 Band's net earnings from sales of 500,000 records

(divided by 4) number of people in band, assuming equal division among members

$\$ 19,725$ Individual member's final paycheck.

These figures exclude lawyer's fees, and the expense of video production (an average of $\$ 75,000$ for MTV-quality production). Given that the above numbers involve approximately a two-year process, each member earns less than $\$ 10,000$ annually, before taxes-hardly the riches that are often assumed to accompany fame and notoriety. 
